\title{
A Process for Reducing the Licensing Burden for New Products Containing Depleted Uranium
}

Environmental Assessment Division Argonne National Laboratory

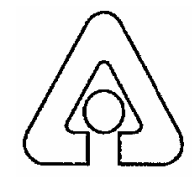

Operated by The University of Chicago, under Contract W-31-109-Eng-38, for the

\section{United States Department of Energy}


Argonne National Laboratory, a U.S. Department of Energy Office of Science laboratory, is operated by The University of Chicago under contract W-31-109-Eng-38.

DISCLAIMER
This report was prepared as an account of work sponsored by an agency of
the United States Government. Neither the United States Government nor
any agency thereof, nor The University of Chicago, nor any of their
employees or officers, makes any warranty, express or implied, or assumes
any legal liability or responsibility for the accuracy, completeness, or
usefulness of any information, apparatus, product, or process disclosed, or
represents that its use would not infringe privately owned rights. Reference
herein to any specific commercial product, process, or service by trade name,
trademark, manufacturer, or otherwise, does not necessarily constitute or
imply its endorsement, recommendation, or favoring by the United States
Government or any agency thereof. The views and opinions of document
authors expressed herein do not necessarily state or reflect those of the
United States Government or any agency thereof.

Available electronically at http://www.doe.gov/bridge

Available for a processing fee to U.S. Department of Energy and its contractors, in paper, from:

U.S. Department of Energy

Office of Scientific and Technical Information

P.O. Box 62

Oak Ridge, TN 37831-0062

phone: (865) 576-8401

fax: (865) 576-5728

email: reports@adonis.osti.gov 


\section{A Process for Reducing the Licensing Burden for New Products Containing Depleted Uranium}

by N.L. Ranek, S. Kamboj, H.M. Hartmann, and H. Avci

Environmental Assessment Division

Argonne National Laboratory, 9700 South Cass Ave., Argonne, Illinois 60439

November 2003

Work sponsored by Oak Ridge National Laboratory under contract to the U.S. Department of Energy, Office of the Deputy Assistant Secretary of Site Closure, Oak Ridge Office, Oak Ridge, Tennessee 


\section{NOTICE}

This technical memorandum is an information product of Argonne's Environmental Assessment Division (EAD). It presents results of ongoing work or work that is more limited in scope and depth than that described in formal reports issued by EAD. This memorandum has undergone internal technical review and has been edited according to EAD's quality assurance requirements. In contrast to a formal technical report, this memorandum has not been externally peer reviewed.

For more information on the division's scientific and engineering activities, contact:

Director, Environmental Assessment Division

Argonne National Laboratory

Argonne, Illinois 60439

Telephone (630) 252-3107

email: ead@anl.gov

Publishing support services were provided by Argonne's Information and Publishing Division (for more information, see IPD's home page: http://www.ipd.anl.gov). 


\section{CONTENTS}

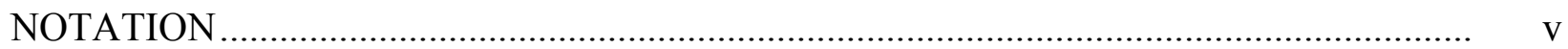

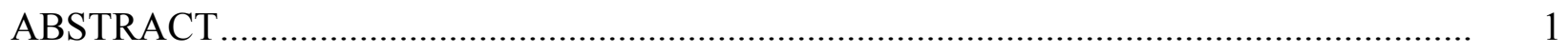

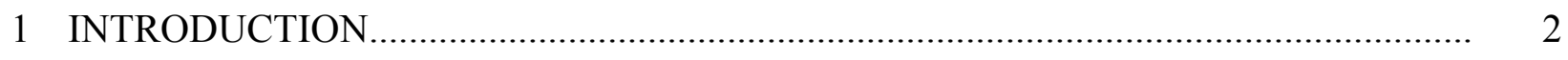

1.1 Background ........................................................................................... 2

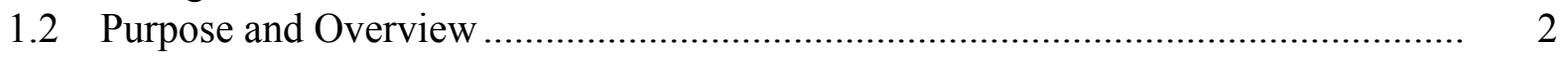

2 THE NRC RULEMAKING PROCESS................................................................ 5

2.1 Generic Requirements for NRC Rulemaking ............................................... 5

2.2 General Licenses for Products Containing Source Material.................................... 5

2.3 Exemptions from NRC Licensing Requirements for Products

Containing Source Material ......................................................................... 7

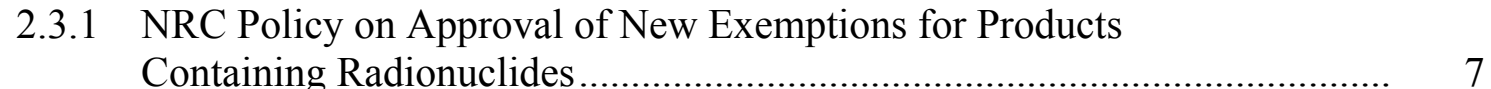

2.3.2 Existing Exemptions for Uranium-Containing Products and Devices ......... 10

2.3.3 NRC Staff Evaluation of Source Material Distribution to Exempt Persons and to General Licensees ............................................ 17

2.4 NRC Guidance on Preparation of an Environmental Report to Support

a Rulemaking Petition Seeking an Exemption for a

Radionuclide-Containing Product...................................................................... 19

3 RISK EVALUATION METHODOLOGIES ...................................................... 25

3.1 Methodologies for Evaluating Radiological Impacts during

Normal Life Cycle, Accidents, and Misuse ..................................................... 26

3.1.1 Normal Life Cycle — NUREG-1717 Approach

to Defining Exposure Scenarios............................................................. 27

3.1.1.1 Distribution and Transport of Products..................................... 28

3.1.1.2 Routine Use of Products ........................................................ 30

3.1.1.3 End-of-Life Disposition of Products........................................ 30

3.1.2 Accidents and Misuse - NUREG-1717 Approach

to Defining Exposure Scenarios.......................................................... 34

3.2 Methodology for Evaluating Chemical Hazards................................................ 35

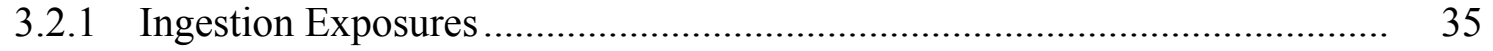

3.2.2 Inhalation Exposures..................................................................... 36

3.3 Assessment of Other Potential Areas of Impact ............................................... 37

3.3.1 Terrestrial and Aquatic Ecology ........................................................... 37

3.3.2 Uses of Land, Air, and Water ........................................................... 37

3.3.3 Socioeconomic Impacts .................................................................. 38

3.3.4 Irreversible Commitment of Resources ............................................... 38 


\section{CONTENTS (Cont.)}

4 SUMMARY AND RECOMMENDATIONS ..........................................................

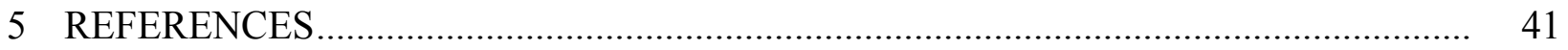

APPENDIX A: Dose Factors, Dose-to-Source Ratios, and Uranium Isotope

Mass and Activity Abundances Assumed for Estimating

Exposures from DU-Containing Products

\section{FIGURES}

2.1 NRC Rulemaking Process Flow Diagram.........................................................

3.1 Pathway from DUF 6 Conversion to End-of-Life Disposition..................................... 25

\section{TABLES}

2.1 NRC Rulemaking Petition Contents ................................................................ 6

2.2 Exemptions in 10 CFR Part 40 for Uranium-Containing Products and Devices ........... 11

2.3 Estimates of Exposures from Exempt Uranium-Containing Products ......................... 12

2.4 Standard Contents of an Environmental Report to Support a Rulemaking

Petition Seeking an Exemption for a Radionuclide-Containing Product ....................... 20

A.1 Mass and Activity Abundances for U-234, U-235, and U-238 in DU ....................... 45

A.2 Dose Factors for Commercial Truck Transport of Products Containing DU ............... 46

A.3 Dose Factors for Air Transport, Warehousing, and Retailing of Products Containing DU ................................................................................... 46

A.4 Pathway-Specific Dose-to-Source Ratios from Disposal of Products Containing DU

A.5 Individual and Collective Dose-to-Source Ratios from Disposal of Products Containing DU ..................................................................................... 48

A.6 Dose-to-Source Ratios from Accidents Involving Products Containing DU................ 48 


\section{NOTATION}

The following is a list of the acronyms, initialisms, and abbreviations (including units of measure) used in this document.

\section{ACRONYMS, INITIALISMS, AND ABBREVIATIONS}

\begin{tabular}{|c|c|}
\hline ADAMS & Agencywide Documents Access and Management System \\
\hline AEA & Atomic Energy Act \\
\hline AEC & Atomic Energy Commission \\
\hline ANL & Argonne National Laboratory \\
\hline $\mathrm{BRC}$ & below regulatory concern \\
\hline CFR & Code of Federal Regulations \\
\hline DOE & U.S. Department of Energy \\
\hline DSR & dose-to-source ratio \\
\hline DU & depleted uranium \\
\hline DUF $_{6}$ & depleted uranium hexafluoride \\
\hline EDE & effective dose equivalent \\
\hline EIS & environmental impact statement \\
\hline EPA & U.S. Environmental Protection Agency \\
\hline FR & Federal Register \\
\hline FRC & Federal Radiation Council \\
\hline HDS & hydrodesulfurization \\
\hline ICRP & International Commission on Radiological Protection \\
\hline MEI & maximally exposed individual \\
\hline NCRP & National Council on Radiation Protection \\
\hline NEPA & National Environmental Policy Act \\
\hline $\mathrm{NRC}$ & U.S. Nuclear Regulatory Commission \\
\hline ORNL & Oak Ridge National Laboratory \\
\hline OSHA & Occupational Safety and Health Administration \\
\hline PEC & photoelectrochemical \\
\hline PEL & permissible exposure limit \\
\hline $\mathrm{R} \& \mathrm{D}$ & research and development \\
\hline SOFC & solid oxide fuel cell \\
\hline Stat. & Statutes at Large \\
\hline U.S.C. & United States Code \\
\hline VOC & volatile organic compound \\
\hline
\end{tabular}

\section{UNITS OF MEASURE}

$\begin{array}{ll}\mathrm{Ci} & \text { curie(s) } \\ \mathrm{g} & \text { gram(s) } \\ \mathrm{kg} & \text { kilogram(s) }\end{array}$




$\begin{array}{ll}\mathrm{lb} & \text { pound(s) } \\ \mathrm{m}^{3} / \mathrm{d} & \text { cubic meter(s) per day } \\ \mathrm{m}^{3} / \mathrm{h} & \text { cubic meter(s) per hour } \\ \mu \mathrm{Ci} & \text { microcurie(s) } \\ \mu \mathrm{Ci} / \mathrm{m}^{2} & \text { microcurie(s) per square meter } \\ \mu \mathrm{Ci} / \mathrm{m}^{3} & \text { microcurie(s) per cubic meter } \\ \mu \mathrm{g} / \mathrm{m}^{3} & \text { microgram(s) per cubic meter } \\ \mathrm{mg} & \text { milligram(s) } \\ \mathrm{mg} / \mathrm{kg} / \mathrm{d} & \text { milligram(s) per kilogram per day } \\ \mathrm{mrem} / \mathrm{yr} & \text { millirem(s) per year } \\ \mathrm{mSv} / \mathrm{yr} & \text { milliSievert(s) per year } \\ \mathrm{pCi} & \text { picocurie(s) } \\ \text { person-rem } / \mathrm{yr} & \text { person-rems(s) per year } \\ \text { person-Sv } & \text { person-Sievert(s) } \\ \text { person-Sv/yr } & \text { person-Sievert(s) per year }\end{array}$




\title{
A PROCESS FOR REDUCING THE LICENSING BURDEN FOR NEW PRODUCTS CONTAINING DEPLETED URANIUM
}

by

\author{
N.L. Ranek, S. Kamboj, H.M. Hartmann, and H. Avci
}

\begin{abstract}
This report is intended to provide guidance on the process for petitioning the U.S. Nuclear Regulatory Commission (NRC) to initiate a rulemaking that could reduce the licensing burden for new products containing depleted uranium (DU), which are being investigated by the DU Uses Research and Development (R\&D) Program at Oak Ridge National Laboratory (ORNL). The focus is on requirements of the NRC rulemaking process applicable to establishing new exemptions or general licenses for products and devices containing source material. NRC policies and guidance regarding such requirements are described, including a 1965 policy statement on approval of new exemptions for products containing radionuclides (Federal Register, Volume 30, page 3462 [30 FR 3462]; March 16, 1965) and Regulatory Guide 6.7, which addresses the contents of environmental reports that support rulemaking petitions seeking exemptions for radionuclide-containing products. Methodologies for calculating radiological and nonradiological impacts on human health (i.e., risks) associated with distributing, using, and disposing of DU-containing products are presented. Also, methodologies for completing assessments of the potential effects of accidents involving new DU-containing products and of product misuse are described. The report recommends that the U.S. Department of Energy formulate a regulatory plan for deployment of DU-containing products in areas that are not already radiologically controlled. Such a plan is needed because deployment of new DU-containing products may be difficult under existing NRC licensing requirements. To provide a basis for the regulatory plan, it is recommended that detailed assessments of the radiological and nonradiological risks of distributing, using, and disposing of DU-containing products be conducted. Such assessments should be initiated as soon as sufficient data are available from the ongoing DU Uses R\&D Program at ORNL to support the analyses.
\end{abstract}




\section{INTRODUCTION}

\subsection{BACKGROUND}

The U.S. Department of Energy (DOE) is funding depleted uranium (DU) uses research and development (R\&D) at Oak Ridge National Laboratory (ORNL). Among other things, the DU Uses R\&D Program implements the conclusion in the DUF 6 Materials Use Roadmap (DOE 2001) that basic research investigations should be conducted to evaluate the feasibility, impacts, and economics of new beneficial uses for depleted uranium hexafluoride (DUF6) conversion products. New beneficial uses for $\mathrm{DUF}_{6}$ conversion products for which investigations are under way include several uses that would place DU in areas that are not already subject to radiological controls. These are uses such as catalysts (for destroying volatile organic compounds [VOCs] in off-gases from industrial processes and for hydrodesulfurization [HDS] of petroleum fuels), semiconductors (for fabricating integrated circuits, solar cells, or thermoelectric devices, especially if such articles are expected to be used in hostile environments), or electrodes (for service in solid oxide fuel cells [SOFCs], batteries, and photoelectrochemical [PEC] cells used to produce hydrogen).

The $D U F_{6}$ Materials Use Roadmap recognized that institutional influences, particularly the applicable regulatory structure, could affect the feasibility and economics of new beneficial uses for $\mathrm{DUF}_{6}$ conversion products. As a result, under subcontract to ORNL, Argonne National Laboratory (ANL) was tasked with analyzing the effects of the existing regulatory structure on deployment of new beneficial DU uses into areas that are not already subject to radiological controls. The results were reported in Regulation of New Depleted Uranium Uses (Ranek 2002). Ranek (2002) concluded that existing regulations would require users of most new DU-containing products and devices to obtain specific source material ${ }^{1}$ licenses from the U.S. Nuclear Regulatory Commission (NRC) or an Agreement State, and that pending regulatory changes are not likely to alter the situation. The report surmises that persons not already subject to NRC or Agreement State regulations may hesitate to purchase new DU-containing products or devices because of the licensing requirements. Thus, as a starting point for formulating a regulatory strategy, Ranek (2002) recommends that DOE evaluate the human health risks of deploying new DU-containing products in areas that are not already radiologically controlled.

\subsection{PURPOSE AND OVERVIEW}

The DU Uses R\&D Program has not yet produced enough information about any of the new DU-containing products being researched to allow detailed assessments of the risks of distribution, use, and disposal of such products. For this reason, it is not possible in this report to

1 The NRC regulations define source material as "(1) uranium or thorium, or any combination thereof, in any physical or chemical form, or (2) ores which contain by weight one-twentieth of one percent $(0.05 \%)$ or more of: (i) uranium, (ii) thorium, or (iii) any combination thereof. Source material does not include special nuclear material" [Code of Federal Regulations (CFR), Title 10, Part 40, Section 40.4 (10 CFR 40.4; NRC 2003b)]. Pursuant to this definition, DU is source material. 
provide a risk analysis or to recommend a specific regulatory strategy for deploying DU-containing products. However, on the basis of the conclusions in Ranek (2002), it seems clear that unless the NRC regulations are changed to reduce the licensing burden, deployment of new DU-containing products into areas not already subject to radiological controls may be difficult. Thus, the purpose of this report is to describe the process for petitioning the NRC to initiate a rulemaking that could reduce the licensing burden for new DU-containing products. For example, a rulemaking to establish a new exemption from NRC licensing requirements for a new DU-containing product would significantly reduce the licensing burden for that product. A rulemaking to establish a new general license also would reduce the licensing burden, but to a lesser degree.

Chapter 2 discusses the process for petitioning the NRC to initiate a rulemaking. NRC requirements and policies related specifically to rulemakings that would add new licensing exemptions for radionuclide-containing products are described. Also, an update is provided about an ongoing NRC evaluation of the impacts on human health and safety from existing exemptions for source material.

Chapter 3 presents methodologies for completing radiological and nonradiological impact assessments that would be necessary to support any petition for NRC rulemaking to establish an exemption or general license for a new DU-containing product. In addition, Chapter 3 generally describes methods that could be used for assessing certain other types of impacts that would also have to be addressed in such a petition.

A summary and recommendations are provided in Chapter 4. 


\section{THE NRC RULEMAKING PROCESS}

\subsection{GENERIC REQUIREMENTS FOR NRC RULEMAKING}

Any person may initiate the NRC rulemaking process by filing a petition in the manner described in Title 10, Part 2, Section 2.802 of the Code of Federal Regulations [10 CFR 2.802 (NRC 2003a)]. The contents of such a petition are listed in Table 2.1.

After receiving a petition for rulemaking, the NRC would process the petition according to the steps depicted in Figure 2.1. As Figure 2.1 indicates, a complete petition would be assigned a docket number. In addition, the NRC would request comments from the public by posting the petition on the NRC Web site and possibly by publishing it in the Federal Register (FR). Then, on the basis of the merits of the petition, the NRC staff would either deny the petition or publish a notice of proposed rulemaking. If a notice of proposed rulemaking was published, comments would be requested from the public and a public hearing might be held. Lastly, after taking the public input into account, the NRC would publish either a final rule or a notice withdrawing the proposed rulemaking.

\subsection{GENERAL LICENSES FOR PRODUCTS CONTAINING SOURCE MATERIAL}

General licenses are granted by NRC or Agreement State regulations and are effective without the filing of applications or the issuance of licensing documents to particular persons, although some general licensees must register with the agency having regulatory authority. The NRC regulations currently contain seven general licenses for source material. Ranek (2002) concluded that, of these, the general license in 10 CFR 40.22 would be the only one potentially available to users of new DU-containing products. ${ }^{2}$ However, Ranek (2002) also concluded that, even though this general license would be potentially available, its provisions sufficiently restrict the one-time and annual amounts of source material that may be transferred and received that it probably would actually be available to only a few users of new DU-containing products. Accordingly, before the availability of general licenses could reduce the licensing burden for new DU-containing products, new general licenses would have to be added to the NRC regulations by initiating the NRC rulemaking process.

The NRC has adopted no separate criteria applicable to approval through the rulemaking process of new general licenses. Notwithstanding, the NRC's policy and procedures for implementing the National Environmental Policy Act (NEPA 1970) require that the regulatory analyses submitted by any person petitioning the NRC to establish an exemption from licensing

2 Section 40.22 of 10 CFR grants a general license to commercial and industrial firms, research, educational, and medical institutions, and federal, state, and local government agencies to use and transfer not more than $15 \mathrm{lb}$ of source material at any one time for research, development, educational, commercial, or operational purposes. A person authorized to use or transfer source material, pursuant to this general license, may not receive more than a total of $150 \mathrm{lb}$ of source material in any one calendar year. In addition, such a person would be exempt from NRC standards for protection of workers and the public against ionizing radiation from licensed activities. 
TABLE 2.1 NRC Rulemaking Petition Contents

Description of Contents

Reference

- The suggested regulatory text of the requested exemption. This text should be worded as directly, clearly, concisely, and unambiguously as possible, and, if possible, should be in the form of an amendment to existing NRC regulations.

- A clear and concise statement of the petitioner's grounds for and interest in the requested exemption.

- A regulatory analysis addressing the factors that would be relevant to making a regulatory decision and would provide the NRC staff with a basis for determining whether to proceed with the proposed rulemaking. Such factors may include the following:

- The specific issues that prompt the petition, which should be described in sufficient detail to enable the NRC staff to easily recognize the problem within the existing regulatory framework.

- The petitioner's views and arguments with respect to the issues should be described in sufficient detail to enable the NRC staff to easily recognize the following:

- The conclusions reached and the bases for these conclusions.

- The sources and magnitude of uncertainties that might affect the conclusions and the proposed new regulatory provisions; and

- The sensitivity of the conclusions to changes in underlying assumptions and considerations.

- Relevant data, which should be provided in sufficient detail to enable the NRC staff to easily recognize the specific data used, analytical methods used, and logic that led to the conclusion that the proposed new regulatory provisions are appropriate and justified.

- Other pertinent information, such as the following:

- Identification of reasonable alternatives to the proposed rulemaking, including a preliminary analysis of the feasibility, values, and impacts of each alternative.

- Evaluation of environmental impacts as described in 10 CFR Part 51, which contains the NRC regulations implementing the National Environmental Policy Act.

or to authorize a general license for the use of radioactive material in a product include an environmental report [10 CFR 51.40 and 51.68 (NRC 2003c)]. Section 2.4 provides information about the required contents of such environmental reports, which must include assessments of radiological and nonradiological impacts (i.e., risks) from normal distribution, use, and disposal of the product and from accidents. 


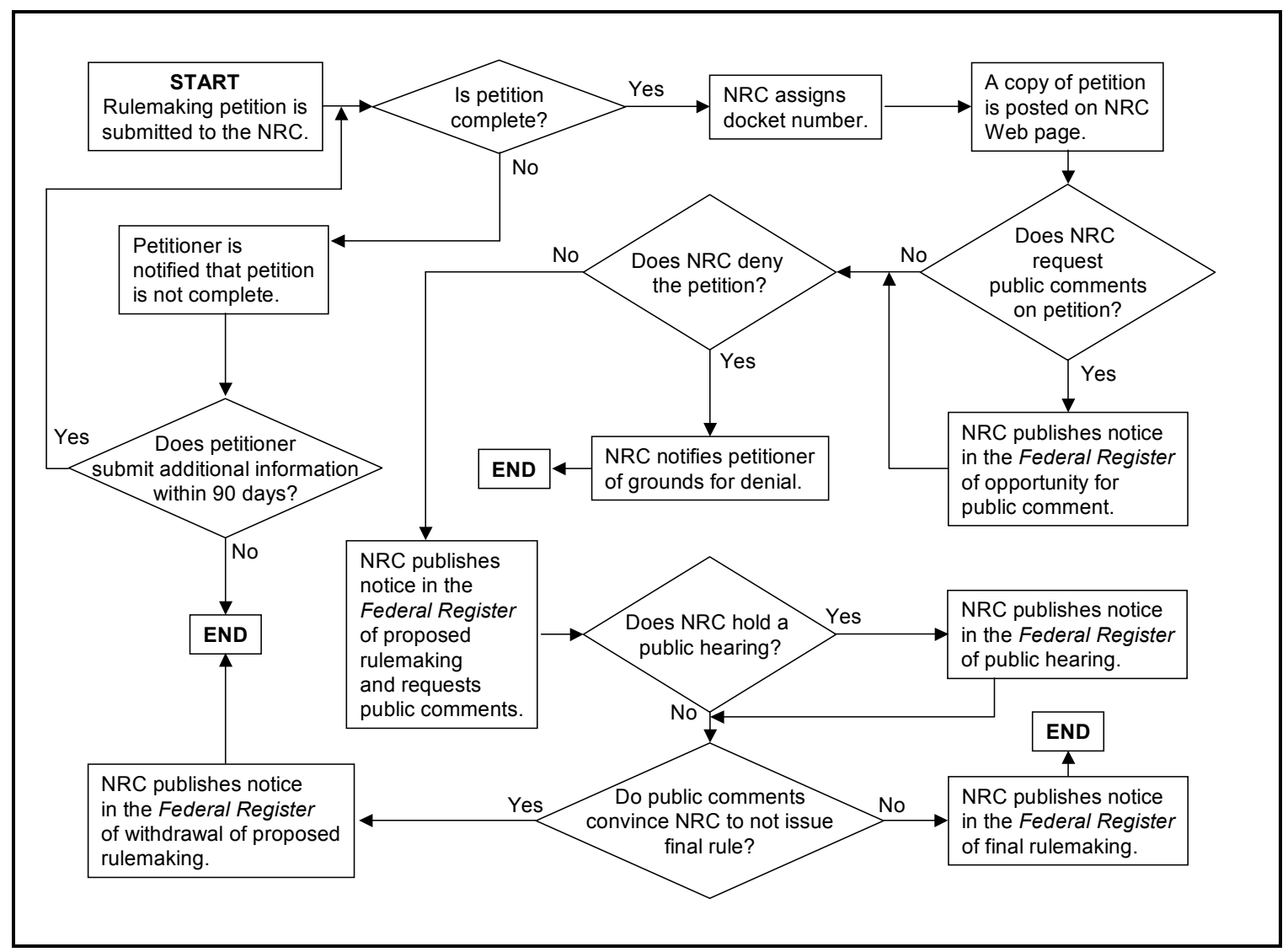

FIGURE 2.1 NRC Rulemaking Process Flow Diagram (Source: adapted from 10 CFR Part 2, Subpart H)

\subsection{EXEMPTIONS FROM NRC LICENSING REQUIREMENTS FOR PRODUCTS CONTAINING SOURCE MATERIAL}

Section 62 of the Atomic Energy Act of 1954 (AEA 1954) requires any person who transfers, delivers, receives, imports, or exports source material to obtain a general or specific license from the NRC. In addition, Section 62 authorizes the NRC to establish "unimportant quantities" of source material that may be transferred and received without a general or specific license. This statutory provision has been interpreted as authorizing the NRC, at its discretion, to establish licensing exemptions for products containing source material.

\subsubsection{NRC Policy on Approval of New Exemptions for Products Containing Radionuclides}

In 1965, the Atomic Energy Commission (AEC) (now the NRC) published a policy statement that discusses criteria for the case-by-case approval of exemptions from licensing 
requirements for products that contain source material or byproduct material ${ }^{3}$ and are intended for use by the general public. This policy statement, which remains effective, ${ }^{4}$ establishes the following general criteria for approval of individual product exemptions [30 FR 3462; March 16, 1965 (AEC 1965)].

Approval of a proposed [exemption for a] consumer product will depend upon both associated exposures of persons to radiation and the apparent usefulness of the product. In general, risks of exposure to radiation will be considered to be acceptable if it is shown that in handling, use and disposal of this product it is unlikely that individuals in the population will receive more than a small fraction, less than a few hundredths, of individual dose limits recommended by such groups as the International Commission on Radiological Protection (ICRP), the National Council on Radiation Protection and Measurements (NCRP), and the Federal Radiation Council (FRC), and that the probability of individual doses approaching any of the specified limits is negligibly small. Otherwise, a decision will be more difficult and will require a careful weighing of all factors, including benefits that will accrue or be denied to the public as a result of the Commission's action.

The term "consumer product" was not defined in the 1965 AEC policy and it has not been defined in the NRC regulations. While in the past the term has sometimes been given a more limited scope, the NRC now considers consumer products to be "those commodities, devices, or products that, following manufacture, can be possessed, used, transferred, or disposed of in an uncontrolled manner because persons possessing and using them are exempt from licensing requirements" (NRC 1990a).

The 1965 AEC policy statement further indicates that the principal considerations with respect to evaluation of proposals for the use of radioactive materials in products are the following (AEC 1965):

(a) The potential external and internal exposure of individuals in the population to radiation from the handling, use and disposal of individual products;

(b) The potential total accumulative radiation dose to individuals in the population who may be exposed to radiation from a number of products;

3 The NRC regulations define "byproduct material" to be "any radioactive material (except special nuclear material) yielded in or made radioactive by exposure to the radiation incident to the process of producing or utilizing special nuclear material" [10 CFR 30.4 (NRC 2003g)].

4 On July 3, 1990, the NRC published the "Below Regulatory Concern," or "BRC," policy statement in the Federal Register. It was intended to supersede the 1965 AEC policy [55 FR 27522 (NRC 1990b)]. However, after the public expressed considerable concern about the implications of the BRC policy, Congress acted to revoke it in the Energy Policy Act of 1992 (EPAct) (Pub.L. 102-486). This resulted in formal withdrawal of the BRC policy statement by the NRC on August 24, 1993 [58 FR 44610 (NRC 1993)]. 
(c) The long-term potential external and internal exposure of the general population from the uncontrolled disposal and dispersal into the environment of radioactive materials from products authorized by the Commission; and

(d) The benefit that will accrue to or be denied the public because of the utility of the product by approval or disapproval of a specific product.

Finally, the policy statement lists the following factors that will be considered, along with other pertinent case-specific factors, when a detailed evaluation of potential exposures from a particular product is warranted (AEC 1965):

- The external radiation levels from the product.

- The proximity of the product to human tissue during use.

- The area of tissue exposed. A dose to the skin of the whole body would be considered more significant than a similar dose to a small portion of the skin of the body.

- Radiotoxicity of the radionuclides. The less toxic materials with a high permissible body burden, high concentration limit in air and water, would be considered more favorably than materials with a high radiotoxicity.

- The quantity of radioactive material per individual product. The smaller the quantity the more favorably would the product be considered.

- Form of material. Materials with a low solubility in body fluids will be considered more favorably than those with a high solubility.

- Containment of the material. Products that contain the material under very severe environmental conditions will be considered more favorably than those that will not contain the material under such conditions.

- Degree of access to product during normal handling and use. Products that are inaccessible to children and other persons during use will be considered more favorably than those that are accessible.

In addition to the guidance provided above, the policy statement includes some general rules indicating that the following types of products are unlikely to be approved for exemption from regulation (AEC 1965):

- Products with questionable tangible benefits to the public that could result in widespread use of radioactive material in households. Examples may be toys, novelties, and adornments. 
- Off-the-shelf items that are subject to mishandling, especially by children, unless they are found to combine an unusual degree of utility and safety.

\subsubsection{Existing Exemptions for Uranium-Containing Products and Devices}

Table 2.2 lists the exemptions for uranium-containing products that the NRC regulations already provide. The NRC approved all of these exemptions from 1947 through 1970. Generally, the basis for approval given by the NRC staff in each notice of final rulemaking relied on a qualitative evaluation indicating that the product would have benefit and would cause radiation doses of only a small fraction of the dose limits recommended at the time by the FRC, NCRP, and ICRP (NRC 1990a). Quantitative dose estimates were not provided.

Interestingly, in 1975, the NRC denied some petitions advocating an exemption from licensing for the use of depleted uranium in commercial products for mass-volume applications. The reason given for the denial was the potential for uranium-containing products or devices to ultimately enter into scrap-processing systems instead of being properly disposed of as radioactive waste (NRC 1990a).

Over the years, as new data caused reductions in the dose limits recommended by the FRC, NCRP, and ICRP, the NRC has occasionally reevaluated the regulatory exemptions in 10 CFR Part 40. Most recently, Systematic Radiological Assessment of Exemptions for Source and Byproduct Materials (NRC 2001b) (referred to as NUREG-1717) was prepared as a basis for such a reevaluation, which is currently ongoing. It consists of comprehensive assessments of potential and likely doses that might occur as a result of the radionuclide-containing products covered by existing exemptions (including exemptions for products that contain source material and products that contain byproduct material).

Table 2.3 identifies the annual effective dose equivalent $(\mathrm{EDE})^{5}$ for highly exposed individuals, as estimated in NUREG-1717, for each of the eight currently exempt uraniumcontaining products listed in Table 2.2. None of the annual individual dose estimates for routine use of a currently exempt uranium-containing product exceeds $100 \mathrm{mrem} / \mathrm{yr}(1 \mathrm{mSv} / \mathrm{yr})$, which is the maximum allowable dose rate for an individual member of the public, as established in the NRC regulations [10 CFR 20.1301 (NRC 2003f)]. The annual individual dose estimates for such products range from less than $0.001 \mathrm{mrem} / \mathrm{yr}(0.00001 \mathrm{mSv} / \mathrm{yr})$ to $90 \mathrm{mrem} / \mathrm{yr}(0.09 \mathrm{mSv} / \mathrm{yr})$, with two products having dose rates greater than or equal to $10 \mathrm{mrem} / \mathrm{yr}(0.1 \mathrm{mSv} / \mathrm{yr})$ but less than $100 \mathrm{mrem} / \mathrm{yr}(1 \mathrm{mSv} / \mathrm{yr})$, two products having dose rates greater than or equal to $1 \mathrm{mrem} / \mathrm{yr}$ $(0.01 \mathrm{mSv} / \mathrm{yr})$ but less than $10 \mathrm{mrem} / \mathrm{yr}(0.1 \mathrm{mSv} / \mathrm{yr})$, and the remaining four products having dose rates less than $1 \mathrm{mrem} / \mathrm{yr}(0.1 \mathrm{mSv} / \mathrm{yr})$.

Since the results in NUREG-1717 were intended for use in evaluating the impact of existing exemptions on human health and safety, such results are not necessarily indicative of

5 The EDE is the uniform dose to the whole body considered to have an impact on the health of the individual equivalent to the impact that the actual doses to various organs would have. 
TABLE 2.2 Exemptions in 10 CFR Part 40 for Uranium-Containing Products and Devices

\begin{tabular}{|c|c|c|c|}
\hline Exemption & $\begin{array}{c}\text { Examples of Exempt } \\
\text { Uranium-Containing Products }\end{array}$ & $\begin{array}{l}\text { Citation } \\
(10 \mathrm{CFR}) \\
\end{array}$ & $\begin{array}{c}\text { Date Final Exemption } \\
\text { Was Published }\end{array}$ \\
\hline $\begin{array}{l}\text { Chemical mixture, compound, } \\
\text { solution, or alloy containing } \\
<0.05 \text { percent by weight of source } \\
\text { material }\end{array}$ & $\begin{array}{l}\text { Dental prostheses } \\
\text { Dental porcelain }\end{array}$ & 40.13(a) & $\begin{array}{l}\text { January } 14,1961 \\
\quad(26 \text { FR 284) }\end{array}$ \\
\hline $\begin{array}{l}\text { Glazed ceramic tableware } \\
\text { containing }<20 \text { percent by weight of } \\
\text { source material }\end{array}$ & $\begin{array}{l}\text { Plates, dishes, bowls, cups, and } \\
\text { saucers (in six-piece sets) }\end{array}$ & 40.13(c)(2)(i) & $\begin{array}{l}\text { January } 14,1961 \\
\quad(26 \text { FR 284) }\end{array}$ \\
\hline $\begin{array}{l}\text { Piezoelectric ceramic containing not } \\
\text { more than } 2 \text { percent by weight of } \\
\text { source material }\end{array}$ & $\begin{array}{l}\text { Gyroscopes for military } \\
\text { applications, accelerometers, and } \\
\text { other sensors for aerospace } \\
\text { applications; high-frequency delay } \\
\text { lines used in the broadcasting } \\
\text { industry to convert TV signals }\end{array}$ & 40.13(c)(2)(ii) & $\begin{array}{c}\text { April 18, } 1970 \\
\text { (35 FR 6313) }\end{array}$ \\
\hline $\begin{array}{l}\text { Glassware containing not more than } \\
10 \text { percent by weight source material } \\
\text { but not including commercially } \\
\text { manufactured glass brick, pane } \\
\text { glass, ceramic tile, or other glass or } \\
\text { ceramic used in construction }\end{array}$ & $\begin{array}{l}\text { Drinking glasses, wine glasses, } \\
\text { tumblers, candy dishes, vases, } \\
\text { pitchers, goblets, ash trays, } \\
\text { candlestick holders, and other } \\
\text { ornamental and decorative objects }\end{array}$ & 40.13(c)(2)(iii) & $\begin{array}{l}\text { January } 14,1961 \\
\quad(26 \text { FR 284) }\end{array}$ \\
\hline $\begin{array}{l}\text { Photographic film, negatives, and } \\
\text { prints containing uranium or } \\
\text { thorium }\end{array}$ & $\begin{array}{l}\text { Old black and white photographic } \\
\text { prints }\end{array}$ & $40.13(c)(3)$ & $\begin{array}{l}\text { March 20, } 1947 \\
(12 \text { FR 1855) }\end{array}$ \\
\hline $\begin{array}{l}\text { Uranium contained in } \\
\text { counterweights installed in aircraft, } \\
\text { rockets, projectiles, and missiles }\end{array}$ & $\begin{array}{l}\text { Counterweights and ballasts used } \\
\text { to balance hinge points and control } \\
\text { surfaces (rudders, stabilizers, } \\
\text { ailerons, and elevators) of aircraft }\end{array}$ & $40.13(c)(5)$ & $\begin{array}{l}\text { September } 9,1969 \\
\quad(34 \text { FR 14067) }\end{array}$ \\
\hline $\begin{array}{l}\text { Natural or depleted uranium metal } \\
\text { used as shielding constituting part of } \\
\text { any shipping container }\end{array}$ & $\begin{array}{l}\text { Containers designed for the } \\
\text { transport of gamma-ray sources, } \\
\text { such as radiography sources }\end{array}$ & $40.13(c)(6)$ & $\begin{array}{l}\text { November } 22,1961 \\
\quad(26 \text { FR 10929) }\end{array}$ \\
\hline $\begin{array}{l}\text { Detector heads for use in fire } \\
\text { detection units, provided that each } \\
\text { detector head contains not more than } \\
0.005 \mu \mathrm{Ci} \text { of uranium }\end{array}$ & $\begin{array}{l}\text { Prototype fire detectors (only two } \\
\text { or three were built, none were } \\
\text { manufactured for sale) }\end{array}$ & $40.13(d)$ & $\begin{array}{l}\text { December 27, } 1963 \\
\quad(28 \text { FR 14309) }\end{array}$ \\
\hline
\end{tabular}




\section{TABLE 2.3 Estimates of Exposures from Exempt Uranium-Containing Products}

\begin{tabular}{|c|c|c|c|c|}
\hline Product & $\begin{array}{l}\text { Annual EDE for } \\
\text { Highly Exposed } \\
\text { Individual } \\
(\mathrm{mrem} / \mathrm{yr})^{\mathrm{a}}\end{array}$ & $\begin{array}{c}\text { Annual } \\
\text { Collective } \\
\text { EDE } \\
\text { (person- }_{\text {rem/yr) }} \\
\end{array}$ & $\begin{array}{c}\text { Total Collective } \\
\text { Dose } \\
\text { Equivalent } \\
\text { (person-rem) }^{\mathrm{a}} \\
\end{array}$ & Notes \\
\hline
\end{tabular}

\section{Dental products containing}

$<0.05 w t \%$ uranium

\section{Glazed ceramic tableware ${ }^{1}$}

Distribution

Routine use ${ }^{2}$

- As dinnerware

- On display

Disposal

Misuse

\section{Piezoelectric ceramic}

Distribution and transport

Routine use

Disposal

- Landfills

- Incineration

Accidents and misuse

-Fire

-Carrying in pocket
0.05

50

$0.06^{3}$

0.4

0.4

0.005

$0.2^{6}$

$<0.001^{7}$

$<0.001^{7}$

$0.07^{8}$

$0.01^{9}$
50$$
-
$$$$
-
$$$$
-
$$$$
-
$$

$\mathrm{NA}^{\mathrm{c}}$

$$
-
$$

$4,000^{4}$

8

$\mathrm{NA}^{\mathrm{c}}$

$\begin{array}{cc}- & 0.0001^{5} \\ - & 0.1^{5} \\ - & 0.006^{5} \\ - & 0.00002^{5} \\ - & \text { NA } \\ - & \text { NA }\end{array}$

1. Unless noted otherwise, dose estimates for glazed ceramic tableware are based on the assumption that the glaze contains the maximum amount of uranium allowed under the exemption, which is $20 \%$ by weight.

2. Tableware is assumed to be used in six-piece place settings either as dinnerware in the home, or as a display in a home or museum setting for an average of 20 years.

3. On display in the home.

4. The collective dose for dinnerware on display is based on $14 \%$ uranium and an annual distribution of 6,000 sets of tableware.

5. Collective doses are based on an assumed annual distribution of 200,000 piezoelectric devices containing $12 \mathrm{mg}$ of natural uranium per device and an assumed useful lifetime of 10 years for products or instruments containing the piezoelectric devices.

6. Dose estimate applies to a user who is routinely exposed to a large piezoelectric device containing $90 \mathrm{~g}$ of natural uranium.

7. Dose estimate applies to waste collectors at the landfill or incinerator.

8. Dose estimate applies to a worker who is involved in the cleanup following a fire involving a single large transducer (90 $\mathrm{g}$ of uranium) and who does not wear a respirator.

9. Dose estimate applies to whole-body irradiation of a repair person carrying a 12-mg uranium (1\%) device in a coveralls pocket; dose estimate for the annual dose equivalent from beta particles to a small area of skin beneath the pants pocket of the coveralls could be $4 \mathrm{mSv}$ (400 mrem). At the $2 \%$ exemption limit, the estimated doses would be twice these values. 
TABLE 2.3 (Cont.)

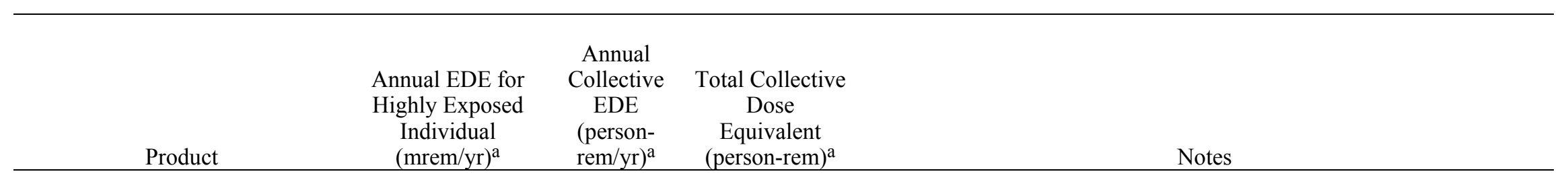

\section{Glassware}

Distribution and transport

Routine use ${ }^{11}$

- As drinking glasses

- On display

Disposal - Incinerators

Accidents and misuse

$4^{10}$

$2^{12}$

$0.2^{12}$

$0.8^{10}$

\section{Photographic films, negatives,}

\section{and prints}

Distribution and transport

Routine use

Disposal

- Landfills

- Incinerators

Accidents and misuse

- Ingestion by small child

- Fire

\section{$<0.001^{13}$ \\ $0.03^{15}$ \\ $<0.001^{16}$ \\ $<0.001^{16}$}

$60^{17}$

$0.04^{18}$
$50^{10}$

$60^{10}$

$10,000^{10}$

$20^{10}$

NA
10. Distribution, disposal, and all collective doses for glassware use an assumed average concentration of $5 \%$ uranium by weight.

11. Glassware is assumed to be used or on display for an average of 20 years.

12. Individual dose rates for routine use of glassware assumed an average concentration of $10 \%$ uranium by weight.

14. Collective doses are based on the existence of 10,000 photographs having an average lifetime of 50 years and containing $1 \mathrm{~g}$ each of natural uranium.

$<0.001^{14}$

$<0.001^{14}$

15. Dose estimate applies to exposure to one photograph during routine home use for 1 year.

NA

16. Dose estimate applies to waste collectors at the landfill or incinerator.

17. Dose estimate applies to a 1-year-old child who chews on a photograph and ingests $0.1 \mathrm{~g}$, or $10 \%$, of the natural uranium on the photograph.

18. Dose estimate applies to person escaping from a residential fire or neighborhood hero attempting to rescue person from a residential fire. 
TABLE 2.3 (Cont.)

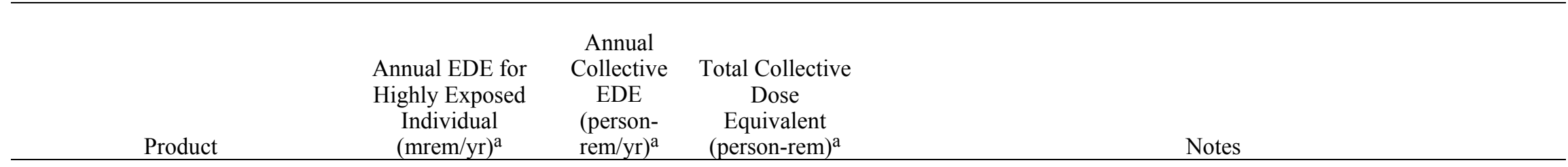

\section{Uranium in Counterweights}

Transport - Driver

Routine use

- Installation and removal

- Flight operations

- Storage

Disposal - Landfill ${ }^{2}$

Recycle operations ${ }^{24}$

Accidents and misuse

- Aircraft incident involving

$$
\text { fire }
$$

- Storage facility involving fire

- Loss/misuse
0.4

90

119

0.03

$0.02^{22}$

2

$30^{25}$

$40^{26}$

$80^{27}$
0.1

1

$300^{20}$

0.002

$0.6^{23}$

NA

$-$

NA

$-$
19. Dose estimate applies to flight attendant who spends 1,000 hours per year in flight.

20. Collective doses are based on an estimated $3.9 \times 10^{7}$ total passengers per year in planes containing DU counterweights.

21. Aging aircrafts containing counterweights are eventually taken out of service and salvaged. It is assumed that, since the counterweights are exempt from licensing, some could be inadvertently disposed of as waste in municipal landfills.

22. Dose estimate applies to waste hauler.

23. Collective doses are based on groundwater consumption near landfills assuming an annual disposal rate of 60 counterweights, each containing $15 \mathrm{~kg}$ of uranium, for 30 years.

24. Metals from salvaged aircraft are likely to be recycled in smelters. It is assumed that DU counterweights may be commingled with such metals. Accordingly, some DU counterweights, which are exempt from licensing, could be inadvertently melted in the smelters.

25. Dose estimate applies to firefighter.

26. Dose estimate applies to cleanup worker.

27. Dose estimate applies to a salvage worker who saws or cuts a DU counterweight creating airborne particulate. 
TABLE 2.3 (Cont.)

\begin{tabular}{|c|c|c|c|c|}
\hline Product & $\begin{array}{l}\text { Annual EDE for } \\
\text { Highly Exposed } \\
\text { Individual } \\
\text { (mrem/yr) }^{\mathrm{a}}\end{array}$ & $\begin{array}{l}\text { Annual } \\
\text { Collective } \\
\text { EDE } \\
\text { (person- }_{\text {rem/yr) }}\end{array}$ & $\begin{array}{c}\text { Total Collective } \\
\text { Dose } \\
\text { Equivalent } \\
\text { (person-rem) }^{\mathrm{a}}\end{array}$ & Notes \\
\hline
\end{tabular}

\section{Uranium Shielding in Shipping}

\section{Containers}

Distribution and transport

- Production facility to source fabrication facility

- Source fabrication facility to industrial user

Disposal - landfill ${ }^{32}$

- On-site worker -

Operational period

- On-site receptor -

Post-closure period

Transportation accident

- Cask transport

- Radiographic devices

$\begin{array}{ccc}0.3^{28} & 0.003^{29} & - \\ 5^{30} & 0.1^{31} & - \\ 0.5^{33} & 2^{34} & - \\ - & - & 200^{35} \\ 30^{36} & - & - \\ 7^{36} & - & -\end{array}$

28. Dose estimate applies to a motor freight driver.

29. One hundred cask shipments per year are assumed. Twenty percent of cask shipments are assumed to be by motor freight. Eighty percent of cask shipments are assumed to be by air transport. The amount of depleted uranium in a shipping cask is assumed to be about $60 \mathrm{~kg}$ 30. Dose estimate applies to airfreight transport loader.

31. Two thousand source shipments per year are assumed. Ten percent are assumed to be by motor freight and $90 \%$ are assumed to be by airfreight transport.

32. While DU shipping containers are expected to be reused or recycled in most instances, it is possible that disposal of empty containers in municipal landfills could occur since these containers are exempt from licensing.

33. Dose estimate applies to on-site waste collector.

34. Approximately 3,500 municipal landfills are assumed to be active.

35 . Assumes that 1 device per year containing $16 \mathrm{~kg}$ of depleted uranium will be disposed of in each of approximately 3,500 municipal landfills for a period of 30 years. Then, at each landfill, closure will occur and on-site occupation will commence by 10 receptors for a period of 30 years.

36. Dose estimate applies to a worker involved in the cleanup following a transportation accident in which a fire ensues. A shipping cask is assumed to contain $60 \mathrm{~kg}$ of depleted uranium. A radiographic shipping container is assumed to contain $16 \mathrm{~kg}$ of depleted uranium. 


\section{TABLE 2.3 (Cont.)}

\begin{tabular}{|c|c|c|c|c|}
\hline Product & $\begin{array}{l}\text { Annual EDE for } \\
\text { Highly Exposed } \\
\text { Individual } \\
(\mathrm{mrem} / \mathrm{yr})^{\mathrm{a}}\end{array}$ & $\begin{array}{l}\text { Annual } \\
\text { Collective } \\
\text { EDE } \\
\text { (person- } \\
\text { rem/yr) }\end{array}$ & $\begin{array}{c}\text { Total Collective } \\
\text { Dose } \\
\text { Equivalent } \\
\text { (person-rem) }^{\mathrm{a}} \\
\end{array}$ & Notes \\
\hline
\end{tabular}

\section{Fire Detection Units Containing}

\section{Uranium}

Distribution and transport

$-$

Routine use - household

Disposal

- Landfill

- Incinerator

Accidents and misuse

- Warehouse fire

- Residential fire

- Transportation fire

- Misuse

$0.05^{37}$
$<0.001^{38}$
$<0.001^{39}$
$0.004^{40}$
$0.009^{41}$
$<0.001^{42}$
$0.04^{43}$
$<0.001^{44}$

$-$

$-$

$-$

$-$

(person-rem) $^{\mathrm{a}}$

Notes

7. Dose estimate applies to a forklift operator in a warehouse where smoke detectors are stored.

38. Dose estimate applies to a homeowner who purchases, installs, and maintains the detector, and who occupies the house where it is located.

39. Dose estimate applies to landfill workers.

40. Dose estimate applies to a waste collector at an incinerator.

41. Dose estimate applies to a worker involved in the cleanup following a warehouse fire.

42. Dose estimate applies to a person escaping a household fire, as well as a firefighter and a worker involved in the cleanup following the fire.

43. Dose estimate applies to a worker involved in the cleanup following a transportation accident in which a fire ensues.

44. Dose estimate applies to a teacher who removes a $0.005-\mu \mathrm{Ci}$

uranium source from a smoke detector for use in classroom

demonstrations about radioactivity.

a $1 \mathrm{mrem} / \mathrm{yr}=0.01 \mathrm{mSv} / \mathrm{yr} ; 1$ person-rem/yr $=0.01$ person-Sv/yr; 1 person-rem $=0.01$ person-Sv.

b A dash indicates that no estimated value was reported in NUREG-1717. With respect to this, total collective doses were not estimated in NUREG-1717 if an exempt product was not being produced and was not in wide-scale use at the time the NUREG was written, since there was no basis for such an assessment.

c $\mathrm{NA}=$ not applicable.

Source: Adapted from NUREG-1717 (NRC 2001b). 
dose levels that the NRC would find acceptable for exempting uranium-containing products in the future. Notwithstanding, the methodology used in NUREG-1717 for calculating dose estimates may provide insight into approaches that the NRC staff would find acceptable in a petition seeking a new exemption for a new DU-containing product. Those methodologies are described in Chapter 3.

\subsubsection{NRC Staff Evaluation of Source Material Distribution to Exempt Persons and to General Licensees}

The assessments in NUREG-1717 of potential and likely doses resulting from existing exemptions for radionuclide-containing products were performed to allow the NRC staff to evaluate whether regulatory action should be taken to ensure public health and safety. The Part 40 Rulemaking Working Group, which the NRC convened in 2000, is conducting the evaluation.

The Part 40 Rulemaking Working Group consists of representatives from the Organization of Agreement States, the Conference of Radiation Control Program Directors, Inc., and the NRC staff. This Working Group learned from the results reported in NUREG-1717 that uses of certain exempt products containing source material (e.g., thorium-containing welding rods) have the potential to cause doses to individual members of the public in excess of $100 \mathrm{mrem} / \mathrm{yr}(1 \mathrm{mSv} / \mathrm{yr})$ under very conservative scenarios. This raised a concern about the potential impacts on public health and safety of all existing source material exemptions. The concern was heightened by the Working Group's inability to conduct more realistic impact assessments because existing regulations contain no mechanism for the NRC to readily discover the types and quantities of source materials being used under exemptions. Hence, in a report dated April 25, 2001, the NRC staff recommended a rulemaking plan that included the following components, among others (NRC 2001a):

- Addition of a requirement that a specific license be obtained (1) to distribute any product containing source material to an exempt person, and (2) to commercially transfer source material to a person who qualifies for the general license in 10 CFR 40.22.

- Elimination of the existing exemptions for source material in 10 CFR 40.13, if warranted, based on dose assessments and other considerations. 
- Broadening of the applicability of the general license in 10 CFR $40.25^{6}$ to include all new depleted uranium products (including depleted uranium shielding).

If the rulemaking plan recommended by the NRC staff had been implemented, all new DU-containing products would have become covered by the general license in 10 CFR 40.25. It is unclear whether the NRC would have considered granting new exemptions for such products thereafter. However, in June 2003, the NRC Commissioners disapproved the recommended rulemaking plan and directed the NRC staff to proceed instead with the following actions, among others (NRC 2003d):

- Compile additional available information (from states, the U.S. Environmental Protection Agency [EPA], and the Occupational Safety and Health Administration [OSHA]) about the products and quantities of source material distributed and used by exempt persons and general licensees.

- If necessary, collect information from a select number of licensees, on a voluntary basis, to confirm the available data.

- Conduct an assessment of the need for any regulatory changes using scenarios and models that represent more realistic estimates of potential exposures than those used in NUREG-1717.

- Provide the NRC Commissioners with the results of the assessment and any follow-up recommendations for changes in the regulatory program. If appropriate, the recommendations could include collecting needed information from significant source materials distributors to formulate a recommendation on potential rulemaking.

- Grant the petition for rulemaking dated August 30, 1999, which describes a need for revised regulations to define and clarify responsibilities for the effective control of depleted uranium counterweights when they are removed from service (Philotechnics 1999).

The NRC staff has yet established the schedule for implementing the June 2003 directive from the NRC Commissioners (NRC 2003e). Therefore, for the purpose of this report, it is

6 Section 40.25 of 10 CFR grants a general license to persons who receive, acquire, possess, use, or transfer depleted uranium contained in industrial products or devices for the purpose of providing a concentrated mass in a small volume of the product or device. To qualify for the general license, the product or device must have been manufactured or initially transferred in accordance with a specific license issued either by the NRC pursuant to 10 CFR 40.34(a) or by an Agreement State pursuant to equivalent state regulations. In addition, the person receiving the depleted uranium must notify the NRC and comply with certain restrictions on handling and transferring the material. Because of the constraint in this general license on the purpose for which depleted uranium is to be used, Ranek (2002) concluded that the general license in 10 CFR 40.25 would not be available to users of new DU-containing products that may result from uses being investigated as part of the DU Uses R\&D Program. 
assumed that petitioning for exemptions from regulation for new DU-containing products will continue to be an option.

\subsection{NRC GUIDANCE ON PREPARATION OF AN ENVIRONMENTAL REPORT TO SUPPORT A RULEMAKING PETITION SEEKING AN EXEMPTION FOR A RADIONUCLIDE-CONTAINING PRODUCT}

The NEPA requires that all federal agencies prepare detailed environmental statements on proposals for legislation and other major federal actions significantly affecting the quality of the human environment. As part of its policy and procedures for implementing the NEPA, the $\mathrm{NRC}$ requires that the regulatory analyses submitted by any person petitioning the NRC to establish an exemption from licensing or to authorize a general license for the use of radioactive material in a product include an environmental report [10 CFR 51.40 and 51.68 (NRC 2003c)]. Detailed guidance on the contents of such a petitioner's environmental report is provided in Regulatory Guide 6.7 (NRC 1976). Table 2.4 summarizes this guidance.

As Table 2.4 suggests, when a new exemption from licensing or a new general license is sought for the use of radioactive material in a product, Regulatory Guide 6.7 indicates inclusion in the petitioner's environmental report of assessments of the following potential impacts from the product's normal distribution, use, and end-of-life disposition: radiological and nonradiological impacts on human health, on terrestrial and aquatic ecology, on land, air, and water use, and on other resources; adverse and beneficial impacts on the economic and social aspects of the community; and irreversible commitments of resources. In addition, Regulatory Guide 6.7 suggests inclusion in the petitioner's environmental report of assessments of the radiological and nonradiological impacts from postulated accidents involving the product and from product misuse. Chapter 3 presents methodologies for completing radiological and nonradiological impact assessments. Chapter 3 also generally describes methods that could be used for assessment of the other types of impacts indicated by Regulatory Guide 6.7. 
TABLE 2.4 Standard Contents of an Environmental Report to Support a Rulemaking Petition Seeking an Exemption for a Radionuclide-Containing Product

Section Number and Title

Summary

\section{Chapter 1, Introduction}

1.1 The Petition for Rulemaking

1.2 The Petitioner

1.2.1 Description

1.2.2 Relationship to (specific name of product)
Brief Description of Information To Be Included

A concise description of the specific product, a brief comparison of alternatives, and a brief listing of significant environmental impacts associated with the product.

The proposed text for the exemption, the purpose to be served by the exemption, and the pros and cons of granting the exemption.

Petitioner's name and address and a description of the types of products being manufactured.

Clear statement of the petitioner's interest in distribution of the product.

\section{Chapter 2, Description and Use of (specific name of product) That Contains (names of radionuclides)}

2.1 Description

2.1.1 General Construction

2.1.2 The Radionuclides

2.2 Operations

2.3 Uses

2.4 Methods of Use

2.5 Distribution

2.5.1 Packaging

2.5.2 Distribution
Description of how the product is constructed, with emphasis on how the radioactive material is incorporated, including the identity of all radioactive materials contained in the product and a description and drawing of the product.

Detailed description of the radioactive material used, including all radionuclides present and their nuclear properties and abundances, as well as pertinent chemical, biological, and physical data.

Description of how the product functions, with emphasis on the function of the radioactive material.

Description of the use(s) for which the product is designed, as well as possible use(s) not intended by the manufacturer, with emphasis on how the radioactive material facilitates such use(s).

Description of how, where, and by whom the product will be used.

Description of package design, including geometry and composition of package construction materials, labeling, markings, instructions, and radiation dose rates at specified distances from the package.

Characterization of the sites (such as warehouses, freight terminals, or retail stores) where the product will be temporarily located during distribution. 
TABLE 2.4 (Cont.)

Section Number and Title

2.5.3 Transport

2.6 Installation, Maintenance, and Repair

2.7 Disposal
Brief Description of Information To Be Included

List of transport modes and characteristics of shipment for each mode, including, among other things, the radiation dose rate at a specified distance from the shipping vehicle.

Description of the intended methods of performing installation, maintenance, and repair activities relating to radiation safety features of the product, with emphasis on operations during which persons will come into contact with the radioactive material or during which shielding of the radioactive material might be significantly reduced or radioactive material might be released.

Description of likely disposal methods for the product and any efforts to encourage return of the product to the manufacturer for controlled disposal as radioactive waste.

\section{Chapter 3, Market for (name of product) That Contains (names of radionuclides)}

\subsection{Need}

3.1.1 For (general name of product)

3.1.2 For (name of specific product)

3.2 The (name) Industry

\subsection{Demand}

3.3.1 For (general name of product)

3.3.2 For (specific name of product)

3.4 Supply
Description of the need for the product.

Identification of the need for the product and description of how the need is being met now and would be met in the future without the product.

Description of how the specific radionuclide-containing product will fill the need differently from existing or planned products.

Identification of the likely types of manufacturers and distributors of the product (e.g., timepiece manufacturers, medical device manufacturers, firearms manufacturers) and description of their activities related to the radioactive components of the product.

Past, present, and future short- and long-term demands for the general type of product.

Estimates of present and future demand for the specific product.

Demonstration of how the demands given in Section 3.3 have been, are being, and will be met.

\section{Chapter 4, Environmental Effects of Normal Distribution, Use, and Disposal of (Name of Product)}

4.1 Environments and Populations Affected Description of the scenarios for which impacts are to be determined, including the following for each stage in the life span of the product: (1) geographic locations; (2) site and environments; (3) persons involved directly with the stage and their actions; and (4) bystanders or persons not involved directly with, but affected by, the stage and their actions. Stages in the product life span are the following:

(1) Distribution; (2) Use; (3) Installation, Maintenance, and Repair; and (4) Disposal. 
TABLE 2.4 (Cont.)

Section Number and Title

4.2 Radiological Impacts

\subsubsection{On Man}

4.2.2 On Terrestrial and Aquatic Ecology

4.2.3 On Land, Air, and Water Use

4.3 Nonradiological Impacts

4.4 Impacts on the Community

4.4.1 Economic

4.4.2 Social

4.5 Resources Committed
Brief Description of Information To Be Included
Detailed, quantified estimates of the radiation doses (both external doses and dose commitments) to individuals and to the population based on the scenarios given in Section 4.1.

Estimates of radiation doses to and contamination of terrestrial and aquatic flora and fauna based on the scenarios given in Section 4.1.

Estimates of contamination of or restrictions placed on the use of land, air, water, and other resources based on the scenarios given in Section 4.1.

Estimates of nonradiological impacts on man, on terrestrial and aquatic ecology, and on the use of land, air, water, and other resources based on the scenarios given in Section 4.1.

Estimates of the expected magnitude of impacts of the product, both beneficial and adverse, on the following for each stage in the life span of the product: (1) employment; (2) other secondary activities such as crime and energy conservation; (3) tax revenues; (4) services revenues; (5) use of resources; and (6) costs.

Estimates of the expected magnitude of impacts of the product, both beneficial and adverse, on the following for each stage in the life span of the product: (1) community services; (2) national goals and security; and (3) concern about introducing radionuclides into the environment.

Discussion of irreversible commitments of resources involved in manufacturing the product and in its distribution, use, repair, and disposal.

\section{Chapter 5, Environmental Effects of Postulated Accidents or Misuse}

5.1 Radiological Impacts of Accidents

5.2 Nonradiological Impacts of Accidents
For each stage in the life span of the product, description and assessment of credible accidents and misuses of the product in which exposure to or release of the radioactive material is a significant factor.

For each stage in the life span of the product, description and assessment of credible accidents and misuses of the product in which exposure to or release of the radioactive material is not a significant factor, but in which significant personal injury or property loss may occur, with emphasis on potential chemical effects. 
TABLE 2.4 (Cont.)

Section Number and Title

Brief Description of Information To Be Included

\section{Chapter 6, Alternatives}

6.1 Alternative Related to (specific name of product)
6.1.1 Alternative Radionuclides
Description of feasible alternative radionuclides and discussion of why they are not being used.
6.1.2 Other Products or Designs
6.1.3 Other Means of Distribution, Use, and Disposal

6.2 Alternatives Related to Licensing Requirements for (name of product)

6.2.1 General License

6.2.2 Specific License

Chapter 7, Summary of Potential Benefits and Possible Costs

Summary, including a table, of the potential benefits and costs associated with the distribution, use, and disposal of the product, assuming approval of an exemption from licensing and regulatory requirements.

Source: NRC Regulatory Guide 6.7 (NRC 1976). 


\section{RISK EVALUATION METHODOLOGIES}

The pathway by which DUF $_{6}$ conversion products are expected to move from a DOE-controlled conversion facility to new beneficial uses in radiologically uncontrolled areas and, ultimately, to disposal includes the following segments: (1) transfer of DUF $_{6}$ conversion products primarily in the form of DU oxides away from the conversion facility; (2) manufacture of DU-containing devices and products at an NRC-licensed facility ${ }^{7}$; (3) transfer of DU-containing devices and products to users in areas not otherwise required to be radiologically controlled; (4) use of DU-containing devices and products within areas not otherwise required to be radiologically controlled; and (5) disposition of DU-containing devices or products at the end of their useful lives (Ranek 2002). This pathway is illustrated in Figure 3.1. Each segment may result in exposure of workers, the public, and the environment to DU. DOE is evaluating the risks associated with transferring DU conversion products away from conversion facilities in two site-specific environmental impact statements (EISs), one for a conversion facility to be located at the Paducah Gaseous Diffusion Plant site and one for a conversion facility to be located at the Portsmouth Gaseous Diffusion Plant site (68 FR 22368; DOE 2003). The risks associated with the second segment would be evaluated during the NRC licensing process for any facility that manufactures exempt uranium-containing products. The risks associated with the last three segments would need to be addressed during the NRC rulemaking process initiated by a petition

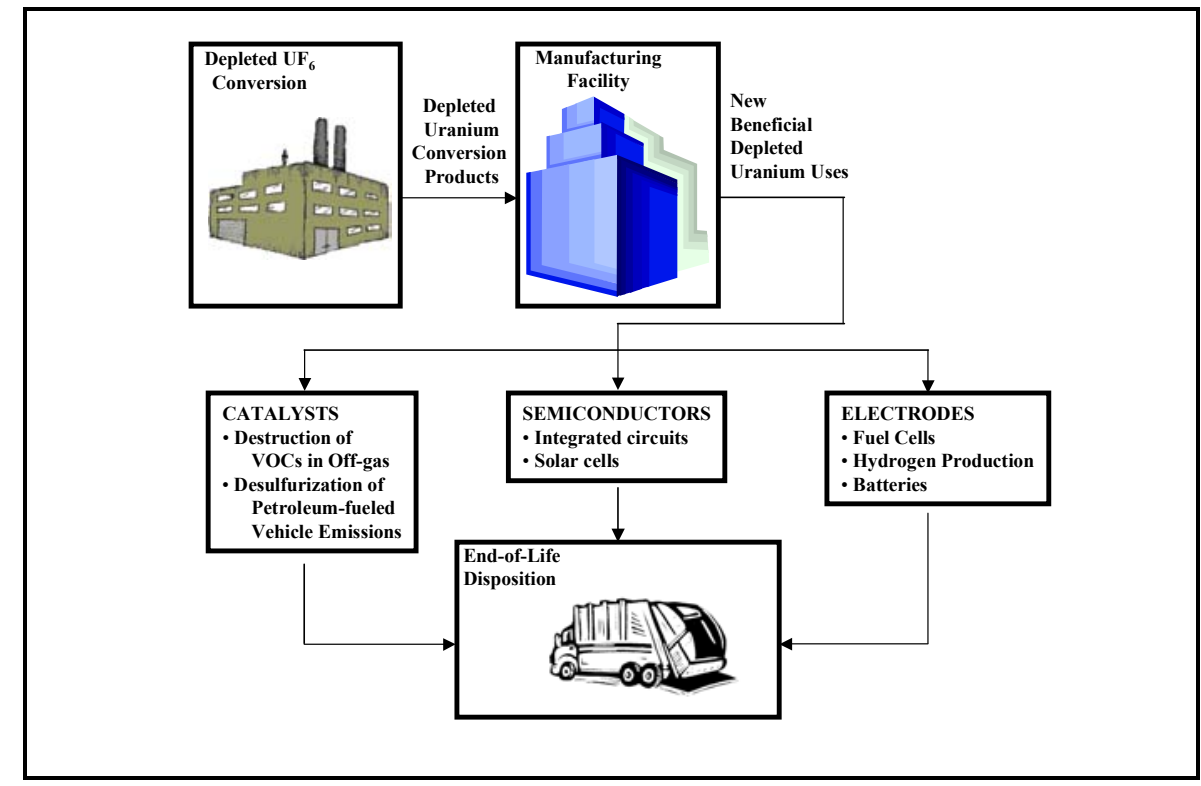

FIGURE 3.1 Pathway from DUF 6 Conversion to End-of-Life Disposition (Source: Ranek 2002)

7 The AEA does not allow the NRC to relinquish to States the regulation of persons who distribute source material to exempt persons (NRC 2001a). Accordingly, only the NRC (not an Agreement State) could license a manufacturing facility that would distribute DU-containing products to users not subject to radiological controls. 
for a new exemption or general license for use of DU-containing devices and products within radiologically uncontrolled areas.

The DU uses for which preliminary research is underway include catalysts (for destroying VOCs in off-gases from industrial processes and for HD of petroleum fuels), semiconductors (for fabricating integrated circuits, solar cells, or thermoelectric devices, especially if such articles are expected to be used in hostile environments), and electrodes (for service in SDFCs, in PEC cells used to produce hydrogen, and in batteries). However, the specific products that will actually be manufactured and deployed are not yet known. For this reason, it is not possible in this report to provide risk analyses like those that would need to be included in petitions for new exemptions or general licenses to support deploying specific DU-containing products. Thus, this chapter focuses on describing methodologies that could be used for completing these risk analyses. Sections 3.1 and 3.2 contain suggestions to be considered in preparing future assessments. Section 3.3 discusses methods for assessing other potential impacts from DU-containing products, such as impacts on terrestrial and aquatic ecology; impacts on land, air, and water use; impacts on social and economic resources; and irreversible commitments of resources.

\subsection{METHODOLOGIES FOR EVALUATING RADIOLOGICAL IMPACTS DURING NORMAL LIFE CYCLE, ACCIDENTS, AND MISUSE}

The NRC regulations do not prescribe methodologies that must be used for analyzing radiological impacts in petitions for new exemptions or general licenses. Therefore, petitioners may use any appropriate methodologies. Even so, as mentioned in Section 2.3.2, the methodologies used by the NRC in NUREG-1717 (NRC 2001b) to assess the radiological impacts on the public from radionuclide-containing products covered by existing licensing exemptions (including exemptions for products that contain source material) may provide insights into approaches that the NRC staff would find acceptable. Thus, the methodologies described and used in NUREG-1717, which are summarized in Section 3.1, may serve as examples for planning radiological impact assessments in future rulemaking petitions seeking new exemptions or general licenses covering DU-containing products. Even so, it is recommended that the NRC staff be consulted on a case-specific basis to ensure that the methodologies used when preparing a particular petition are appropriate.

It should be noted that radiation doses to workers or members of the public during the normal life cycle of an unregulated, DU-containing product and for accidents and misuse of such a product can be estimated by various computer codes. Appendix C of Ranek et al. (1997) provides a list and descriptions of computer codes and models that can assist in converting DU concentrations to radiation dose estimates. For example, the MICROSHIELD (Negin and Worku 1992), RESRAD-BUILD (Yu et al. 2003a), RESRAD-OFFSITE (Yu 2003b), and RESRADRECYCLE (Cheng et al. 2000) computer codes can be used to estimate the external pathway doses from DU-containing products; the RADTRAN (Neuhauser and Kanipe 1992) and RISKIND (Yuan et al. 1995) computer codes can be used to estimate the risk from transportation. 
The descriptions in Sections 3.1.1 and 3.1.2 cover assessments of radiological risk from the normal life cycle stages of unregulated product use and from accidents and misuse, respectively.

\subsubsection{Normal Life Cycle — NUREG-1717 Approach to Defining Exposure Scenarios}

The normal (expected) life cycle stages of unregulated use for which radiological impacts should be evaluated in a petition seeking a new exemption or general license for a DU-containing product are the following:

- Transport and distribution of the DU-containing product to members of the public,

- Intended or expected routine use of the DU-containing product, and

- Disposition of the DU-containing product.

For each life stage, individual and collective (population) doses should be estimated based, respectively, on the amount of DU in each unit of the product and the total amount of DU assumed to be distributed annually in all units of the product. In calculating doses, exposure routes to be accounted for should include inhalation, ingestion, and external exposure. In general, however, no inhalation or ingestion exposures would be expected during transport/distribution and routine use of DU-containing products, because the DU would be contained in a stable form within the products and not be easily removed or suspended in air. Typically, results would be presented as EDEs.

Generally, individual doses during the three normal life cycle stages listed above could be estimated in the form of annual (yearly) doses for those groups of individuals expected to receive the highest exposures. Estimates should account for radioactive decay and ingrowth, if such factors would be significant.

Collective doses during each stage of the normal life cycle of a DU-containing product should also be estimated. In NUREG-1717, collective doses are presented in the form of total doses over time for assumed annual distributions of radioactive material. When this approach is used, the methods for determining total collective doses for the different life cycle stages are as follows:

- The collective dose from distribution and transport of a product is assumed to be experienced only during the same year as the initial distribution.

- The collective dose from routine use is determined over the useful lifetime of the product. For example, if a DU-containing product has an expected lifetime of 10 years, the collective dose would be the sum over 10 years of the dose from the amount of DU assumed to be distributed in each year. 
- The collective dose from end-of-life disposition is the dose during the same year that disposals occur for some population groups (e.g., workers at the disposal facility), but is the total dose over time after disposal for other population groups (e.g., persons expected to occupy the waste disposal site following closure of the disposal facility).

The estimates of individual and collective doses for distribution and transport, routine use, and end-of-life disposition generally must be based on assumptions about exposure scenarios. For example, in estimating external dose, assumptions would be made about the source configuration, distance between the source and exposed individuals (receptors), the amount of shielding between the source and receptor locations, and the amounts of time receptors spend near the source. Similarly, in estimating inhalation dose, assumptions would be made about the amount of radioactive material released from the product into the air, the size and ventilation rate of the air space into which the material would be released, the breathing rate of individuals, and the exposure time. For estimates of ingestion dose, assumptions would be made about the radioactive material released and the fraction of the released material that would be ingested.

In NUREG-1717, the purpose of the study was to provide a systematic assessment of potential radiological impacts on the public associated with a wide variety of products or materials and practices that are already exempt from NRC licensing requirements. To simplify the analyses, standard assumptions were used to define exposure scenarios for all dose assessments, to the extent practicable and reasonable. Sections 3.1.1.1 through 3.1.1.3, below, summarize the standard assumptions that were made for each stage of the normal life cycle of exempt products. It should be noted, however, that in spite of the effort in NUREG-1717 to standardize an approach to dose assessments, case-specific exposure scenarios had to be developed for routine use of products because reasonable scenarios varied considerably among the particular products encompassed by the study. Adjustments to the standard assumptions also were often required to ensure that exposure scenarios were appropriate for use in the dose estimates for transport/distribution and end-of-life disposition.

\subsubsection{Distribution and Transport of Products}

The distribution of products containing radioactive material are assumed in NUREG-1717 to be accomplished by direct nonstop commercial truck; by commercial package or mail delivery, which may involve truck and air transport and intermediate freight-handling terminals; and by wholesale and retail firms, which may involve all of the above, plus warehouses, distribution centers, and retail stores. The following is a representative subset of possible distribution and transport scenarios.

- Commercial truck transport, which includes (1) nonstop (express) delivery via small, large, and tractor-trailer trucks; (2) local delivery via small and large trucks; and (3) regional or long-distance transport via small, large, and tractortrailer trucks. 
- Warehousing, which includes handling in large warehouses (e.g., truck terminals) and medium-sized warehouses (e.g., distribution centers).

- Retailing, which involves handling, storage, and display in small and large retail establishments.

- Air transport, which includes handling at receiving and shipping freight terminals and exposures to flight crew and passengers on a regularly scheduled flight.

The defined scenarios are combined to build a model that would be representative of most common distribution schemes. Not all of the steps included in the scenarios were needed to describe delivery of each particular product. In cases that did not need to include all steps, only the appropriate parts of the scenarios were chosen for use in estimating doses. Also, item-specific analyses had to be developed for items with the potential to cause high radiation doses or that are distributed by methods not characterized by the scenarios mentioned above.

In NUREG-1717, individual and collective dose factors are calculated using defined scenarios and methods. The dose factor for a particular radionuclide meeting the definition of source material, such as DU, is the EDE [measured in Sievert $(\mathrm{Sv})$ or rem] associated with distribution of a product containing $1 \mathrm{mg}$ of the radionuclide. As mentioned in Section 3.1.1, DU would be contained in a stable form within new DU-containing products. Consequently, inhalation or ingestion exposures are not expected during transport/distribution of such products, because the DU could not be easily removed or suspended in air. NUREG-1717 reflects this in its assumption that all EDEs associated with distribution of already exempt DU-containing products are the result of external exposures caused by radiation emitted from packages. For ease of reference, Tables A.2 and A.3 in Appendix A report the dose factors used in NUREG-1717 for estimating doses from distribution and transport of exempt uranium-containing products.

If the NUREG-1717 approach of applying dose factors to estimate individual and collective doses is used in the future for a new DU-containing product, the six steps listed below should be followed.

1. Identification and listing of the scenarios involved in the chosen distribution mode.

2. Total quantity of DU to be distributed.

3. Selection of the highly exposed individual dose factors and collective dose factors from Table A.2 or A.3 (located in Appendix A).

4. Multiplication of the dose factors by quantity of DU in the shipment to obtain the individual and collective EDE for each step.

5. Selection of the highly exposed individual EDE for all steps. 
6. Addition of the collective EDEs for all steps to get the total EDE for the shipment.

NUREG-1717 points out that use of this approach for calculating EDEs will produce estimates of individual and collective doses that are more likely than not to overestimate actual impacts. In the case of DU-containing products, this is likely to occur because DU self-shielding would reduce actual external radiation exposures in comparison to the estimates made by linear scaling, which is inherent in the use of dose factors. Accordingly, in the future, before using dose factors to estimate EDEs from new DU-containing products, the appropriateness of the approach should be evaluated on a case-specific basis.

\subsubsection{Routine Use of Products}

In spite of the desire to establish a uniform, standardized approach to estimating dose for the wide variety of products and materials considered in NUREG-1717, typical scenarios for routine use that would illustrate for all exempt products how to predict distances between the source and exposed individuals, the amount of shielding between the source and receptor locations, or the amount of time spent near the source could not be devised. Thus, NUREG-1717 performed individual and collective dose estimates on a case-by-case basis for routine use of each radionuclide-containing product that is already exempt from NRC licensing requirements. Similarly, in the future, estimates of individual and collective doses from routine use of new DU-containing products should be based on case-specific definitions of exposure scenarios.

\subsubsection{End-of-Life Disposition of Products}

In NUREG-1717, it is assumed that, because exempt radionuclide-containing products are not subject to NRC licensing requirements, such products would be likely to be managed as municipal solid waste at the end of their useful lives (NRC 2001b). Similarly, radionuclidecontaining products that are subject to a general license might be managed as municipal solid waste under unusual circumstances. Furthermore, as NUREG-1717 notes, a large portion of municipal solid waste generated in the United States is sent to landfills or treated in incineration facilities. Thus, in NUREG-1717, individual and collective doses are estimated for scenarios involving direct disposal of reasonable numbers of exempt products in municipal landfills and for scenarios involving incineration of reasonable numbers of exempt products, with the incinerator ash being disposed of in landfills (NRC 2001b). In addition, for the reasons discussed in Section 3.1.1.3.3, NUREG-1717 estimates doses caused by a reasonable number of exempt products that are managed to recover metals at the end of their useful lives.

For each end-of-life management option, NUREG-1717 defines groups of exposed individuals, including workers associated with operations at the landfill, incinerator, and metal smelter, and members of the public who could be exposed in a variety of ways, depending upon the particular option. For the options of landfill disposal and incineration, both individual and collective doses are calculated. However, because recycling to recover metals was judged to be 
an unusual occurrence for most exempted products containing radionuclides, only individual doses are estimated for this option (NRC 2001b).

For each group of exposed individuals and populations associated with an assumed disposition option, NUREG-1717 defines exposure pathways that generally include external exposure, inhalation, and ingestion. Then, for each pathway, radionuclide-specific dose-to-source ratios (DSRs) are calculated for exposed individuals and populations. The DSRs give the EDE per unit quantity of the radionuclides that are expected to be disposed of under the assumed disposition option and the particular exposure pathway. Doses from the products are then estimated using Equation 1.

$$
H_{i j}=D S R_{i j} \times A_{i}
$$

where

$$
\begin{aligned}
H= & \text { EDE from exposure to radionuclide } i \text { for exposure pathway } j, \\
D S R= & \begin{array}{l}
\text { dose-to-source ratio for the particular radionuclide and exposure } \\
\text { pathway, and }
\end{array} \\
A= & \begin{array}{l}
\text { assumed activity of the particular radionuclide disposed of for the } \\
\text { assumed option. }
\end{array}
\end{aligned}
$$

For ease of reference, Tables A.4 and A.5 in Appendix A report the DSRs used in NUREG-1717 for estimating doses from end-of-life disposition of uranium-containing products.

3.1.1.3.1 Disposal in Municipal Landfills. For disposal of radionuclide-containing products in municipal landfills, NUREG-1717 assumes the following four groups of individuals to be exposed: (1) waste collectors, (2) workers at the landfills, (3) off-site members of the public residing near the landfills, and (4) future on-site residents at the landfills. Exposure pathways that are assumed for each group are described in the paragraphs below.

Waste Collectors. Waste collectors are individuals who collect waste from the generating site, haul the waste to garbage trucks, and transport the waste to landfills. Waste collectors are assumed to receive exposures from the following three pathways: (1) external exposure to products containing the radionuclides of concern in the waste containers, (2) inhalation of products containing the radionuclides of concern emitted from the waste containers into the air, and (3) ingestion of products containing the radionuclides of concern in the waste.

Landfill Workers. Workers at landfills are individuals who are located on top of the waste pile during operations and who perform tasks such as dumping of waste, grading of waste, 
and covering of waste at periodic intervals. Landfill workers are assumed to receive exposures from the following three pathways: (1) external exposure to products containing the radionuclides of concern in the waste pile, (2) inhalation of the radionuclides of concern suspended from the waste pile into the air, and (3) ingestion of the radionuclides of concern in the waste pile.

Off-Site Members of the Public. For off-site members of the public who reside near landfills, two different exposure scenarios should be considered. The first scenario, which would occur only during landfill operations, involves releases of products containing the radionuclide of concern into the air and subsequent atmospheric transport to off-site locations. The off-site residents are assumed to receive exposures from the following four pathways: (1) inhalation of airborne radionuclides, (2) external exposure to airborne radionuclides, (3) external exposure to the radionuclides of concern deposited on the ground surface, and (4) ingestion of food products contaminated by deposition of the radionuclides of concern onto the ground surface.

The second exposure scenario, which would occur only after a landfill is closed, involves releases of the radionuclides of concern into groundwater and subsequent transport to a nearby municipal well. The off-site residents should be assumed to receive exposures from the pathway that involves ingestion of the radionuclides of concern in the drinking water obtained from the well.

Future On-Site Resident. At some time after closure of a landfill, members of the public are assumed to establish permanent residency on the landfill site. A suburban housing development is assumed, in which no on-site sources of drinking water would be established. Residents are assumed to receive exposures from the following three pathways: (1) external exposure to products containing the radionuclides of concern in the waste during indoor and outdoor residence on the site, (2) inhalation of the radionuclides of concern suspended from the waste into the air during indoor and outdoor residence on the site, and (3) ingestion of the radionuclides of concern in the waste.

3.1.1.3.2 Incineration. For incineration of products containing radionuclides, NUREG-1717 assumes the following three groups of individuals to be exposed: (1) waste collectors, (2) workers at the incinerators, and (3) off-site members of the public residing near the incinerators. Exposure pathways that are assumed for each group are described in the paragraphs below.

Waste Collectors. For waste collectors at incinerators, the assumed exposure scenario and exposure pathways are the same as those for waste collectors at landfills.

Incinerator Workers. Workers at incinerators are individuals who engage in sweeping or other cleanup activities while located at the edge of a partially enclosed tipping area where 
garbage trucks unload waste at the facility. Workers at incinerators are assumed to receive exposures from the following three pathways: (1) external exposure to radionuclide-containing products in the waste pit, (2) inhalation of the radionuclides of concern suspended from the waste pit into the air, and (3) ingestion of the radionuclides of concern in the waste.

Off-Site Members of the Public. Off-site members of the public who reside near incinerators are assumed to receive exposure from stack releases of radionuclides of concern into the air following waste incineration and subsequent atmospheric transport to off-site locations. The assumed exposure scenario and exposure pathways for airborne releases from an incinerator are the same as those for landfill operations.

When ash from incinerators that treat radionuclide-containing products within municipal solid waste streams is disposed of on the land, it also may contribute to exposure of off-site members of the public. Such exposure can be estimated using the same scenarios described in Section 3.1.1.3.1 for direct disposal of radionuclide-containing products in landfills. However, because solid waste incinerator ash typically also contains toxic metals, it may be characterized as hazardous waste under the Resource Conservation and Recovery Act (RCRA). If this occurs, the additional requirements for treatment and for disposal in specially designed landfills would significantly limit exposure of off-site members of the public to radiation from the ash in comparison to disposal in a nonhazardous solid waste landfill (NRC 2001b).

3.1.1.3.3 Recycling. A substantial fraction of all municipal solid waste generated in the United States is recovered for recycling (NRC 2001b). Since many exempt radionuclidecontaining products are likely to be managed in the municipal solid waste stream at the end of their useful lives, the radiological risks associated with their possible recycling were included in the evaluation in NUREG-1717 of radiological risks from using such products. In addition, radionuclide-containing products that are subject to a general license could accidentally be managed as municipal solid waste and thereby undergo recycling. If it occurs, the recycling of radionuclide-containing products that are either exempt from NRC licensing or subject to a general license is expected to involve processing at a metal smelter to recover metals such as steel or aluminum. Accordingly, NUREG-1717 assumes the following three groups of individuals to be exposed: (1) workers at the smelting facility, (2) off-site members of the public residing near the smelting facility, and (3) members of the public who use the recycled radionuclide-containing products.

Smelter Workers. The slag workers at the smelting facility are assumed to receive the highest doses (NRC 2001b). These workers are assumed to receive exposures from the following three pathways: (1) external exposure to the radionuclides of concern in slag, (2) inhalation of the radionuclides of concern emitted from slag into the air, and (3) ingestion of the radionuclides of concern in slag. 
Off-Site Members of the Public. Off-site members of the public who reside near smelters are assumed to receive exposure from stack releases of the radionuclides of concern into the air following smelting and subsequent atmospheric transport to off-site locations. The assumed exposure scenario and exposure pathways for airborne releases from a smelter should be the same as for airborne releases during landfill operations.

Users of Recycled Products. In NUREG-1717, members of the public are assumed to receive exposures during use of contaminated products containing recycled metals. It is predicted that such exposures from the pathway would only be external exposures. Inhalation and ingestion of radionuclides are not predicted to occur during normal use of products fabricated from recycled metal because such radionuclides would be stabilized within the metal matrix and, absent accidents or misuse, not available for suspension into air or leaching into water.

\subsubsection{Accidents and Misuse - NUREG-1717 Approach to Defining Exposure Scenarios}

In contrast to the dose assessments for the normal life cycle of radionuclide-containing products, which are calculated for both individual and collective exposures, NUREG-1717 estimates only individual doses for accidents and misuse of such products.

NUREG-1717 takes the same approach to performing individual dose estimates for misuse situations as for individual dose calculations during the routine use stage of the normal life cycle of an exempt product. That is, case-by-case estimates are always used to perform individual dose estimates for misuse situations. Thus, in the future, if estimates of individual doses from misuse of new DU-containing products are made, it is recommended that they be based on case-specific definitions of exposure scenarios.

The approaches in NUREG-1717 to performing the individual dose calculations for accidents and for the distribution/transport and disposal stages of the normal life cycle are also similar to each other. In such cases, the analyses are simplified by using standard assumptions to define exposure scenarios for all dose assessments, to the extent practicable and reasonable. In accident situations, many of the same considerations as discussed above for development of exposure scenarios during the distribution/transport and disposal stages of the normal life cycle of radionuclide-containing products are applied. The approach involves developing exposure scenarios that, although unlikely to occur, are plausible for the particular product and thus are likely to provide reasonable upper bounds on doses. DSRs that give the EDE per unit quantity of each radionuclide at risk in an accident are calculated (NRC 2001b). Doses are then estimated from the DSRs. For ease of reference, Table A.6 in Appendix A reports the DSRs developed in NUREG-1717 for use in estimating doses from accidents involving DU-containing products.

The generic methodology applied in NUREG-1717 for estimating radiation doses from accidents addresses the following exposure scenarios: (1) fires involving the release of the radionuclides of concern from the product, (2) spills of the radionuclides of concern in liquid or powder form, and (3) crushing of glass tubes containing radioactive gases. Of these, NUREG-1717 considers only the first two to be potentially applicable to DU-containing products 
or materials. For scenarios involving fires, DSRs are developed for three exposure pathways: inhalation, submersion, and resuspension. For scenarios involving spills in liquid or powder form, DSRs are developed for inhalation and ingestion exposure pathways (NRC 2001b).

In spite of its effort to standardize the approach to dose assessments for accidents, NUREG-1717 found that the DSR methodology does not apply for some exempted products (e.g., uranium-containing glassware, uranium-containing glazed ceramic tableware, and uranium-containing dental products). For such products, dose assessments for accidents had to be completed on a case-specific basis. Accordingly, before using the DSR methodology in the future to estimate EDEs in accident scenarios from any particular new DU-containing product, the appropriateness of the methodology should be evaluated for that product.

\subsection{METHODOLOGY FOR EVALUATING CHEMICAL HAZARDS}

The chemical hazards of uranium are also of potential concern with respect to DU-containing products, because uranium is known to cause kidney toxicity at certain exposure levels. Wherever normal use or accidents could result in exposure to DU through the inhalation or ingestion pathways, the potential for chemical toxicity should be considered in addition to radiological dose and risk. As noted in Section 3.1, in general, for distribution/transport and routine use of new DU-containing products, no inhalation or ingestion exposures would be expected, because the DU would be contained in a stable form within the products and not easily removed or suspended in air. Scenarios that might include ingestion or inhalation scenarios are the end-of-life disposition scenarios (discussed in Section 3.1.1.3) and the accidents and misuse scenarios (discussed in Section 3.1.2). The average daily quantity of uranium intake for the maximally exposed individual (MEI) for each applicable scenario (in $\mathrm{mg} / \mathrm{kg} / \mathrm{d}$ ) can be calculated to be consistent with the assumptions made for the calculation of radiological dose (e.g., the same assumptions would be made for parameters such as amount of DU particulate suspended in air, respirable fraction, and breathing rate of the receptor). Once the intake levels have been estimated, the risks of adverse health effects from ingestion and inhalation can be estimated as described in Sections 3.2.1 and 3.2.2.

\subsubsection{Ingestion Exposures}

For oral exposures to soluble compounds of uranium (e.g., uranyl nitrate hexahydrate, uranyl fluoride), a reference dose (the intake level below which no adverse effects would be expected) of $0.003 \mathrm{mg} / \mathrm{kg} / \mathrm{d}$ has been estimated for use in risk assessments (EPA 2003; based on studies using rabbits ingesting uranyl nitrate hexahydrate in food). In the DU products, the uranium present is likely to be in the form of insoluble oxide compounds (e.g., uranium dioxide $\left[\mathrm{UO}_{2}\right]$, triuranium octaoxide $\left[\mathrm{U}_{3} \mathrm{O}_{8}\right]$ ), which are poorly absorbed from the intestinal tract and thus have a somewhat lower toxicity than soluble uranium compounds. However, results from laboratory studies differ with respect to the extent of absorption of specific soluble and insoluble uranium compounds in different species. When assessing oral intake of a specific uranium compound, the literature should be consulted for data on the extent of absorption of the uranium compound in question. If available, the data should be compared with the absorption data for 
uranyl nitrate hexahydrate and appropriate adjustments should be made to the reference dose. If adequate absorption data are not available, it can be conservatively assumed that the uranium compound of interest is absorbed from the digestive tract to a similar extent as the soluble uranium compounds (i.e., no adjustment would be made for assumed decreased absorption).

To assess the potential for adverse health impacts from ingestion using the reference dose, the estimated average daily intake for the MEI is divided by the reference dose. This quotient, termed the hazard quotient, is an indicator of whether the exposure is likely to result in adverse impacts. A hazard quotient of less than 1 indicates that the exposed person is unlikely to develop adverse human health effects. A hazard quotient of greater than 1 would indicate that adverse effects are possible. This type of assessment for the likelihood of systemic effects assumes that a threshold exposure level exists below which no adverse effects are expected. As such, if the estimated exposure for the MEI would not cause adverse effects, then there would also be no adverse effects in the general population, and assessment of population risk would not be necessary. If the estimated hazard quotient for the MEI were greater than 1, the population risk would be estimated as the number of individuals who might experience adverse health impacts (the number expected to be exposed at levels that would result in a hazard quotient greater than 1).

\subsubsection{Inhalation Exposures}

An inhalation reference concentration (similar to a reference dose but given in units of air concentration, $\mu \mathrm{g} / \mathrm{m}^{3}$ ) for assessing the chemical risk from inhaling uranium compounds is not currently available from standard EPA sources. However, reference levels can be derived by modifying the proposed OSHA permissible exposure limits (PELs) (29 CFR 1910.1000, Subpart Z, as of August 2003) for soluble and insoluble uranium compounds. The 8-hour timeweighted-average PEL for soluble uranium compounds is $0.05 \mathrm{mg} / \mathrm{m}^{3}$; the PEL for insoluble compounds is $0.25 \mathrm{mg} / \mathrm{m}^{3}$. By adjusting the PEL values to account for the increased exposure duration of the general public in comparison with workers (assumed to be 168 hours per week rather than 40 hours per week) and dividing by an uncertainty factor of 10 to account for sensitive subpopulations in the general public, derived uranium inhalation reference levels are generated (i.e., $0.0012 \mathrm{mg} / \mathrm{m}^{3}$ and $0.006 \mathrm{mg} / \mathrm{m}^{3}$ for soluble and insoluble uranium compounds, respectively). These air concentrations can be directly compared to modeled air concentrations for the various scenarios; if modeled concentrations are less than the derived reference concentrations, adverse health impacts from the inhalation pathway are very unlikely.

It is sometimes also useful in conducting the risk assessment to convert the reference concentrations to reference levels in units of $\mathrm{mg} / \mathrm{kg} / \mathrm{d}$. This would be useful in order to consider the combined risks from both inhalation and ingestion pathways for a single maximally exposed receptor. If an inhalation rate of $20 \mathrm{~m}^{3} / \mathrm{d}$ and a standard body weight of $70 \mathrm{~kg}$ are assumed, the result will be derived uranium inhalation reference levels for the general public of $0.0003 \mathrm{mg} / \mathrm{kg} / \mathrm{d}$ for soluble uranium compounds and $0.002 \mathrm{mg} / \mathrm{kg} / \mathrm{d}$ for insoluble uranium compounds. The value for insoluble compounds should be used in assessing potential chemical risks from inhalation of uranium oxide compounds, which are the types of DU compounds most likely to be present in DU products. 
As for the assessment for the ingestion pathway, the estimated average daily inhalation intake for the MEI is divided by the appropriate derived inhalation reference level to obtain the inhalation hazard quotient, and a hazard quotient of less than 1 indicates that the exposed person is unlikely to develop adverse human health effects. To assess the combined risk from inhalation and ingestion pathways, the hazard quotients should be added; if the sum is still less than 1, adverse effects would not be expected.

\subsection{ASSESSMENT OF OTHER POTENTIAL AREAS OF IMPACT}

In addition to the radiological and nonradiological impacts on human health described in Sections 3.1 and 3.2, the use of DU-containing products could potentially have impacts on terrestrial and aquatic ecology; on use of land, air, or water; on local economies or social structures; and on resources. This section discusses methods for assessing these impacts.

\subsubsection{Terrestrial and Aquatic Ecology}

Many ecological impacts are assessed using methods similar to those used to assess impacts on human health. Potential exposures of terrestrial and aquatic species are estimated and compared with appropriate guideline levels to predict whether adverse impacts would be expected. In addition, impacts to wetland areas and threatened and endangered species are evaluated.

For DU-containing products, any ecological impacts would most likely be associated with direct disposal or incineration of DU-containing products (through contamination of soil, surface water, or groundwater, and subsequent exposure of ecological receptors), or possibly with recycling of the products to recover ferrous metal (exposures could occur through airborne releases from smelters).

\subsubsection{Uses of Land, Air, and Water}

Impacts on uses of land, air, or water could occur if these media became contaminated at levels exceeding federal or state standards or guidelines. Again, such impacts would most likely be associated with direct disposal or incineration of DU-containing products or with recycling of the products to recover ferrous metal. Estimating contaminant concentrations in the various media and comparing those concentrations with appropriate reference levels would be used to assess impacts. For example, potential impacts to groundwater from landfill disposal would be assessed by modeling release of uranium from the disposal cell over time and estimating the maximum possible future uranium concentration in the groundwater at the edge of the landfill. 


\subsubsection{Socioeconomic Impacts}

An assessment of socioeconomic impacts would estimate the employment and income associated with distribution, use, and disposal of DU-containing products, as well as impacts to community services such as housing availability, local public finances, and public service employment. Regional economic information from the U.S. Bureau of Economic Analysis would be used to aid in the assessment.

\subsubsection{Irreversible Commitment of Resources}

The magnitude of material and energy resources used in association with the distribution, use, and disposal of the DU-containing product would be analyzed for an assessment of resources irreversibly committed. Estimates of the consumption of fuels for product transport would be included. 


\section{SUMMARY AND RECOMMENDATIONS}

In June 2003, the NRC Commissioners directed the NRC staff to proceed with several data collection initiatives and to assess the need for changes in the existing regulations that govern exemptions and general licenses for products containing source material. No schedule has yet been established whereby the NRC staff will implement the NRC Commissioners' directive. Also, it is unclear whether, after the directive is implemented, the NRC staff will continue to grant new exemptions or general licenses for such products. Even so, this report assumes that petitioning for new exemptions and general licenses will remain an option for reducing the licensing burden on new DU-containing products. Accordingly, the report describes the process for petitioning the NRC to initiate a rulemaking.

A petition for rulemaking that seeks a new exemption or general license for a new DU-containing product would need to be supported by an environmental report assessing radiological and nonradiological impacts on human health and the environment caused by distribution, normal use, and end-of-life disposition. In addition, the environmental report should address the potential effects of accidents involving the new product and of product misuse. Methodologies for completing these assessments are described in this report.

Because deployment of new DU-containing products or devices in areas that are not already radiologically controlled may be difficult without modification of the existing NRC licensing regulations, it is recommended that DOE develop a regulatory plan for product deployment. To provide a basis for such a plan, detailed assessments of the radiological and nonradiological risks of distributing, using, and disposing of DU-containing products should be undertaken using methods such as those described in this report. These assessments should be initiated as soon as sufficient data are available from the ongoing DU Uses R\&D Program at ORNL to support the analyses.

A second recommendation is that NRC staff activities related to modification of $10 \mathrm{CFR}$ Part 40 in ways that could affect the regulatory structure applicable to deployment of new DU-containing products continue to be monitored. This would facilitate identifying opportunities

for timely DOE input into any rulemaking initiative that would affect deployment of DU-containing products. 


\section{REFERENCES}

AEA, 1954, Atomic Energy Act of 1954, Public Law 83-703, as amended, 42 United States Code (U.S.C.) 2011 et seq., Aug. 30.

AEC, 1965, Products Intended for Use by General Public (Consumer Products), 30 FR 3462, March 16.

Cheng, J.-J., et al., 2000, RESRAD-RECYCLE: A Computer Model for Analyzing the Radiological Doses and Risks Resulting from the Recycling of Radioactive Scrap Metal and the Reuse of Surface-Contaminated Material and Equipment, ANL/EAD-3, Argonne National Laboratory, Argonne, Ill., Nov.

DOE, 2001, DUF 6 Materials Use Roadmap, ORNL-6968, Washington, D.C., Aug. 27. Available at http://web.ead.anl.gov/uranium/pdf/DURoadmap.pdf. Accessed Aug. 28, 2003.

DOE, 2003, Notice of Change in National Environmental Policy Act (NEPA) Compliance Approach for the Depleted Uranium Hexafluoride (DUF6), 68 FR 22368, U.S. Government Printing Office, April 28.

EPA, 2003, Integrated Risk Information System (IRIS) Database. Available at http://www.epa.gov/iriswebp/iris/index.html. Accessed Nov. 12.

EPAct, 1992, Energy Policy Act of 1992, Public Law 102-486, U.S. Statutes at Large, 106 Stat. 2776 - 3133, Oct. 24.

Negin, C.A., and G. Worku, 1992, MicroShield Version 4, User's Manual, Grove 92-2, Grove Engineering, Inc., Rockville, Md.

Neuhauser, K.S., and F.L. Kanipe, 1992, RADTRAN 4: Volume 3, User Guide, SAND89-2370, Sandia National Laboratories, Albuquerque, N.M., Jan.

NEPA, 1970, National Environmental Policy Act of 1969, Public Law 91-190, as amended, 42 U.S.C. 4321 - 4370f, U.S. Government Printing Office, Jan. 1.

NRC, 1976, Preparation of an Environmental Report to Support a Rulemaking Petition Seeking an Exemption for a Radionuclide-Containing Product, Regulatory Guide 6.7, Revision 1, U.S. Government Printing Office, June.

NRC, 1990a, Policy and Regulation of Byproduct Material and Source Material in Products Intended for Use by the General Public, ADAMS Accession No. ML032190576, Jan. 1.

NRC, 1990b, Below Regulatory Concern Policy Statement, 55 FR 27522, U.S. Government Printing Office, July 3. 
NRC, 1993, Withdrawal of Below Regulatory Concern Policy Statements, 58 FR 44610, U.S. Government Printing Office, Aug. 24.

NRC, 1996, Preparation of Petition for Rulemaking Under 10 CFR 2.802 and Preparation and Submission of Proposals for Regulatory Guidance Documents, Regulatory Guide 10.12, U.S. Government Printing Office, Dec.

NRC, 2001a, "Draft Rulemaking Plan: Distribution of Source Material to Exempt Persons and to General Licensees and Revision of 10 CFR 40.22 General License," SECY-01-0072, April 25.

NRC, 2001b, Systematic Radiological Assessment of Exemptions for Source and Byproduct Materials, NUREG-1717, U.S. Government Printing Office, June.

NRC, 2003a, Code of Federal Regulations, Title 10, Part 2, Subpart H, "Rulemaking," U.S. Government Printing Office, Jan. 1.

NRC, 2003b, Code of Federal Regulations, Title 10, Part 40, Section 40.4, "Definitions," U.S. Government Printing Office, Jan. 1.

NRC, 2003c, Code of Federal Regulations, Title 10, Part 51, Sections 51.45, "Environmental Report," and 51.68, "Environmental Report — Rulemaking," U.S. Government Printing Office, Jan. 1.

NRC, 2003d, Memorandum to W.D. Travers (Executive Director for Operations) from A.L. Vietti-Cook (Secretary to the NRC) regarding "Staff Requirements - SECY-01-0072 Draft Rulemaking Plan: Distribution of Source Material to Exempt Persons and to General Licensees and Revision of 10 CFR 40.22 General License," June 5.

NRC, 2003e, NRC Regulatory Agenda Semiannual Report January - June 2003, NUREG-0936, Vol. 22, No. 1, U.S. Government Printing Office, Aug.

NRC, 2003f, Code of Federal Regulations, Title 10, Part 20, Section 20.1301, "Dose Limits for Individual Members of the Public," U.S. Government Printing Office, Jan.

NRC, 2003g, Code of Federal Regulations, Title 10, Part 30, Section 30.4, "Definitions," U.S. Government Printing Office, Jan.

Philotechnics, 1999, Letter to J. Decicco (NRC) from D.A. Barbour (Philotechnics) regarding "Depleted Uranium Aircraft Counterweights," Philotechnics Letter No. 99-0870, NRC Document No. PRM 40-28, Aug. 30.

Ranek, N.L., et al., 1997, Review of Processes for the Release of DOE Real and Non-Real Property for Reuse and Recycle, ANL/EAD/TM-78, Argonne National Laboratory, Argonne, Ill., Nov. 
Ranek, N.L., 2002, Regulation of New Depleted Uranium Uses, ANL/EAD/TM/02-5, Argonne National Laboratory, Argonne, Ill., Dec.

RCRA, 1976, Resource Conservation and Recovery Act of 1976, Public Law 94-530, as amended, U.S. Statutes at Large, 90 Stat. 2795, Oct. 31.

Yu, C., et al., 2003a, User's Manual for RESRAD-BUILD Version 3.0, ANL/EAD/03-1, Argonne National Laboratory, Argonne, Ill., June.

Yu, C., 2003b, RESRAD-OFFSITE Computer Code, Beta Version for Test and Evaluation Purposes Only. Available at http://web.ead.anl.gov/resrad/home2/offsite.cfm. Accessed Nov. 12.

Yuan, Y.C., et al., 1995, RISKIND - A Computer Program for Calculating Radiological Consequences and Health Risks from Transportation of Spent Nuclear Fuel, ANL/EAD-1, Argonne National Laboratory, Argonne, Ill., Nov. 


\section{APPENDIX A:}

\section{DOSE FACTORS, DOSE-TO-SOURCE RATIOS, AND URANIUM ISOTOPE MASS AND ACTIVITY ABUNDANCES ASSUMED FOR ESTIMATING EXPOSURES FROM DU-CONTAINING PRODUCTS}

The U.S. Nuclear Regulatory Commission (NRC) recently estimated potential doses associated with existing exemptions for uranium-containing products (NRC 2001). The doses were estimated for the normal life cycle of each exempt product and from accidents and misuse of the products. The normal life cycle includes transport and distribution, routine use, and end-of-life disposition. This appendix provides the values used in NRC (2001) for dose factors associated with transport and distribution and for dose-to-source ratios (DSRs) from end-of-life disposition and from accident and misuse of the products containing depleted uranium (DU). Also provided are mass and activity abundances of uranium isotopes in depleted uranium.

Table A.1 lists mass and activity abundances for uranium-234, uranium-235, and uranium-238 in depleted uranium, as assumed in NRC (2001) for the purpose of calculating dose estimates. One gram of depleted uranium will consist of $3.12 \times 10^{4} \mathrm{pCi}$ of uranium-234, $5.40 \times 10^{3} \mathrm{pCi}$ of uranium-235, and $3.35 \times 10^{5} \mathrm{pCi}$ of uranium-238.

Tables A.2 and A.3 provide dose factors for distribution and transport of products containing DU. All dose factors shown in these tables are based on external exposure and were calculated using a PC version of the CONDOS II code (NRC 2001). Table A.2 contains dose factors for commercial truck transport. The dose factors for a highly exposed individual, an average individual, and the collective population are listed. Commercial truck transport includes express delivery via small, large, and tractor-trailer trucks; local delivery via small and large trucks; and regional delivery via small, large, and tractor-trailer trucks. Table A.3 lists dose factors for air transport, warehousing, and retailing of products containing DU. In each category, dose factors are listed for a highly exposed individual and the collective population. In addition, dose factors in the air transport category are provided to accommodate calculation of doses received at freight terminals as well as during flight. Dose factors in the category of warehousing

TABLE A.1 Mass and Activity Abundances for U-234, U-235, and U-238 in DU

\begin{tabular}{cccc}
\hline Isotope & $\begin{array}{c}\text { Half-life } \\
\text { (years) }\end{array}$ & $\begin{array}{c}\text { Mass } \\
\text { Abundance (\%) }\end{array}$ & $\begin{array}{c}\text { Activity } \\
\text { Abundance (\%) }\end{array}$ \\
\hline & & & \\
U-234 & $2.445 \times 10^{5}$ & 0.0005 & 8.4 \\
U-235 & $7.038 \times 10^{8}$ & 0.25 & 1.5 \\
U-238 & $4.468 \times 10^{9}$ & 99.75 & 90.1 \\
\hline
\end{tabular}

a All values are taken from NUREG-1717 (NRC 2001). 
TABLE A.2 Dose Factors for Commercial Truck Transport of Products Containing DUa

\begin{tabular}{|c|c|c|c|c|c|c|c|c|c|}
\hline \multirow{2}{*}{\multicolumn{2}{|c|}{ Receptor }} & \multicolumn{3}{|c|}{ Express Delivery } & \multicolumn{2}{|c|}{ Local Delivery } & \multicolumn{3}{|c|}{ Regional Delivery } \\
\hline & & $\begin{array}{l}\text { Small } \\
\text { Truck }\end{array}$ & $\begin{array}{l}\text { Large } \\
\text { Truck }\end{array}$ & Semi-truck & $\begin{array}{l}\text { Small } \\
\text { Truck }\end{array}$ & $\begin{array}{l}\text { Large } \\
\text { Truck }\end{array}$ & $\begin{array}{l}\text { Small } \\
\text { Truck }\end{array}$ & $\begin{array}{l}\text { Large } \\
\text { Truck }\end{array}$ & Semi-truck \\
\hline \multicolumn{2}{|c|}{$\begin{array}{l}\text { Highly exposed } \\
\text { individual }^{b}\end{array}$} & $7.1 \times 10^{-12}$ & $1.9 \times 10^{-12}$ & $5.8 \times 10^{-13}$ & $1.4 \times 10^{-11}$ & $4.1 \times 10^{-12}$ & $3.2 \times 10^{-11}$ & $6.2 \times 10^{-12}$ & $5.2 \times 10^{-13}$ \\
\hline \multicolumn{2}{|c|}{$\begin{array}{l}\text { Average } \\
\text { individual }^{c}\end{array}$} & $9.4 \times 10^{-13}$ & $7.0 \times 10^{-13}$ & $4.8 \times 10^{-13}$ & $2.1 \times 10^{-12}$ & $1.7 \times 10^{-12}$ & $1.2 \times 10^{-12}$ & $2.5 \times 10^{-13}$ & $1.7 \times 10^{-14}$ \\
\hline \multicolumn{2}{|c|}{ Collective } & $1.0 \times 10^{-12}$ & $7.3 \times 10^{-13}$ & $4.8 \times 10^{-13}$ & $2.5 \times 10^{-12}$ & $1.8 \times 10^{-12}$ & $1.3 \times 10^{-12}$ & $2.8 \times 10^{-13}$ & $2.2 \times 10^{-14}$ \\
\hline $\mathrm{a}$ & $\begin{array}{l}\text { Units are in } \\
\text { All values ar }\end{array}$ & $\begin{array}{l}\mathrm{rem} / \mathrm{mg} \text { shipp } \\
\text { re extracted } \mathrm{fi}\end{array}$ & $\begin{array}{l}\mathrm{d} \text { for high } \\
\mathrm{m} \text { NUREC }\end{array}$ & $\begin{array}{l}\text { exposed an } \\
-1717 \text { (NRC }\end{array}$ & $\begin{array}{l}\text { verage indivi } \\
01) \text {. }\end{array}$ & duals and per & n-rem/mg sh & ped for coll & ective dose. \\
\hline $\mathrm{b}$ & Package loca & ated near dri & & & & & & & \\
\hline $\mathrm{c}$ & Packą & ter of & area. & & & & & & \\
\hline
\end{tabular}

TABLE A.3 Dose Factors for Air Transport, Warehousing, and Retailing of Products Containing DU

\begin{tabular}{|c|c|c|c|c|c|c|}
\hline \multirow[b]{2}{*}{ Receptor } & \multicolumn{2}{|c|}{ Air Transport } & \multicolumn{2}{|c|}{ Warehousing } & \multicolumn{2}{|c|}{ Retailing } \\
\hline & $\begin{array}{l}\text { Freight } \\
\text { Terminal }\end{array}$ & Airplane & $\begin{array}{c}\text { Large } \\
\text { Warehouse }\end{array}$ & $\begin{array}{c}\text { Medium } \\
\text { Warehouse }\end{array}$ & Large Store & Small Store \\
\hline $\begin{array}{l}\text { Highly exposed } \\
\text { individual }\end{array}$ & $4.7 \times 10^{-13}$ & $2.3 \times 10^{-12}$ & $7.3 \times 10^{-13}$ & $3.7 \times 10^{-12}$ & $5.0 \times 10^{-11}$ & $6.5 \times 10^{-11}$ \\
\hline Collective & $2.4 \times 10^{-12}$ & $4.7 \times 10^{-11}$ & $5.5 \times 10^{-12}$ & $2.1 \times 10^{-11}$ & $8.0 \times 10^{-9}$ & $1.3 \times 10^{-8}$ \\
\hline
\end{tabular}

a Units are in rem/mg shipped for highly exposed individual and person-rem/mg shipped for collective dose. All values are extracted from NUREG-1717 (NRC 2001).

are provided to accommodate calculation of doses received in both large and medium warehouses. Dose factors in the retailing category are provided to accommodate calculation of doses received at both large and small stores.

Tables A.4 and A.5 list DSRs for disposal of products containing DU. Table A.4 provides individual and collective DSRs for waste collectors, workers, and future on-site residents at municipal landfills and for waste collectors and workers at municipal incinerators. Table A.5 provides DSRs for certain combinations of receptors and pathways associated with municipal landfill operations, municipal incinerator operations, and metal smelting operations. In the 
TABLE A.4 Pathway-Specific Dose-to-Source Ratios (DSRs) ${ }^{\text {a }}$ from Disposal of Products Containing DU

\begin{tabular}{lccc}
\hline \multicolumn{1}{c}{ Receptor } & External & Inhalation & Ingestion \\
\hline & & & \\
Waste Collectors at Municipal Landfill & & & \\
$\quad$ Individual & $8.0 \times 10^{-15}$ & $1.2 \times 10^{-14}$ & $5.2 \times 10^{-15}$ \\
Collective & $2.8 \times 10^{-11}$ & $4.4 \times 10^{-11}$ & $1.8 \times 10^{-11}$ \\
& & & \\
Workers at Municipal Landfill & & & \\
$\quad$ Individual & $7.6 \times 10^{-16}$ & $1.4 \times 10^{-15}$ & $1.1 \times 10^{-15}$ \\
Collective & $1.3 \times 10^{-11}$ & $2.4 \times 10^{-11}$ & $1.9 \times 10^{-11}$ \\
& & & \\
Future On-site Residents at Municipal Landfill & & & \\
Individual & $2.5 \times 10^{-15}$ & $3.3 \times 10^{-16}$ & $2.1 \times 10^{-17}$ \\
Collective & $2.6 \times 10^{-9}$ & $3.8 \times 10^{-10}$ & $2.4 \times 10^{-11}$ \\
& & & \\
Waste Collectors at Municipal Incinerators & & & \\
Individual & $1.9 \times 10^{-13}$ & $2.9 \times 10^{-13}$ & $1.2 \times 10^{-13}$ \\
Collective & $2.8 \times 10^{-11}$ & $4.4 \times 10^{-11}$ & $1.8 \times 10^{-11}$ \\
& & & \\
Workers at Municipal Incinerators & & & \\
$\quad$ Individual & & & \\
Collective & $1.5 \times 10^{-16}$ & $7.9 \times 10^{-16}$ & $3.3 \times 10^{-17}$ \\
& $4.4 \times 10^{-14}$ & $2.4 \times 10^{-13}$ & $1.0 \times 10^{-14}$ \\
\hline
\end{tabular}

a Units are in rem/mg for individual and person-rem/mg for collective dose. The DSRs give annual effective dose equivalents from disposal of a unit mass (mg) of DU per year and take into account contributions from the short-lived decay products of U-238 and U-235. All values are extracted from NUREG-1717 (NRC 2001).

category of municipal landfill operations, individual and collective DSRs are provided for (1) off-site residents and releases to air and (2) off-site residents and releases to groundwater. In the category of municipal incinerator operations, individual and collective DSRs are provided for off-site residents and releases to air. In the category of metal smelting operations, individual DSRs are provided for (1) slag workers and a combined pathway covering internal and external exposures and (2) off-site residents and releases to air.

Table A.6 lists the DSRs from accidents involving DU-containing products in fires (transportation, warehouse, and resident) and for spill of a liquid or powder that contains DU in a laboratory-type room. 
TABLE A.5 Individual and Collective Dose-to-Source Ratios (DSRs) ${ }^{\text {a }}$ from Disposal of Products Containing DU

\begin{tabular}{lllcc}
\hline \multicolumn{1}{c}{ Disposal Option } & \multicolumn{1}{c}{ Receptor } & \multicolumn{1}{c}{ Pathway } & Individual & Collective \\
\hline & & & & \\
Municipal landfill & Off-site resident & Airborne releases & $2.1 \times 10^{-16}$ & $1.2 \times 10^{-10}$ \\
Municipal landfill & Off-site resident & Groundwater releases & $9.6 \times 10^{-17}$ & $6.2 \times 10^{-10}$ \\
Municipal incinerators & Off-site resident & Airborne releases & $2.3 \times 10^{-18}$ & $1.4 \times 10^{-11}$ \\
Metal smelting & Slag worker & External, inhalation, and ingestion & $1.3 \times 10^{-12}$ & $\mathrm{NA}^{\mathrm{b}}$ \\
Metal smelting & Off-site resident & Airborne release & $1.7 \times 10^{-15}$ & $\mathrm{NA}$ \\
\hline
\end{tabular}

a Units are in rem $/ \mathrm{mg}$ for individual and person-rem $/ \mathrm{mg}$ for collective dose. The DSRs give annual effective dose equivalents from disposal of a unit mass (mg) of DU per year and take into account contributions from the short-lived decay products of U-238 and U-235. All values are extracted from NUREG-1717 (NRC 2001).

b $\quad \mathrm{NA}=$ not applicable.

TABLE A.6 Dose-to-Source Ratios (DSRs) ${ }^{\mathrm{a}}$ from Accidents Involving Products Containing DU

\begin{tabular}{lcccc}
\hline \multicolumn{1}{c}{ Accident/Misuse Scenario } & Inhalation & Submersion & Resuspension & Ingestion \\
\hline & & & & \\
Transportation accident involving fire & $3.8 \times 10^{-11}$ & $6.1 \times 10^{-15}$ & $4.2 \times 10^{-10}$ & NA \\
Warehouse fire & $7.1 \times 10^{-12}$ & $1.1 \times 10^{-15}$ & $4.7 \times 10^{-11}$ & NA \\
$\begin{array}{l}\text { Residential fire } \\
\text { Spill of a liquid or powder in a }\end{array}$ & $4.4 \times 10^{-11}$ & $7.4 \times 10^{-15}$ & $2.3 \times 10^{-10}$ & NA \\
$\quad$ laboratory-type room & $4.4 \times 10^{-8}$ & $\mathrm{NA}^{\mathrm{b}}$ & $\mathrm{NA}$ & $1.0 \times 10^{-8}$ \\
\hline
\end{tabular}

a Units are in rem $/ \mathrm{mg}$. The DSRs give annual effective dose equivalents from accident or misuse of a unit mass (mg) of DU and take into account contributions from the short-lived decay products of U-238 and U-235. All values are extracted from NUREG-1717 (NRC 2001).

b $\quad \mathrm{NA}=$ not applicable.

\section{APPENDIX A REFERENCE}

NRC, 2001, Systematic Radiological Assessment of Exemptions for Source and Byproduct Materials, NUREG-1717, U.S. Government Printing Office, June. 